\title{
NIEWIERNOŚĆ MAŁŻEŃSKA KRÓLOWEJ ZOFII HOLSZAŃSKIEJ W 1427 R. - PRAWDA, POMÓWIENIE CZY PLOTKA POLITYCZNA? PRÓBA REKONSTRUKCJI WYDARZEŃ NA TLE OSKARŻEŃ INNYCH ŻON JAGIEŁŁY
}

\begin{abstract}
Abstrakt: Elekcja i koronacja Władysława Jagiełły na króla Polski w 1386 r. dawały możliwość pojawienia się w Europie Środkowo-Wschodniej nowej liczącej się dynastii. Wzbudzało to niepokój sąsiadów (Luksemburgowie, Krzyżacy) dążących do osłabienia monarchii polsko-litewskiej. Próby ustalenia zasad powoływania kolejnych władców aktywizowały również przedstawicieli polskiego możnowładztwa. W konfliktach pojawiających się na tym tle wykorzystywano różne metody walki politycznej, w tym plotkę polityczną. $\mathrm{W}$ artykule postawiono tezę, że do wybuchu skandalu związanego $\mathrm{z}$ rzekomą niewiernością królowej doszło około połowy sierpnia 1427 r. na zjeździe generalnym w Wiślicy.
\end{abstract}

Słowa kluczowe: Władysław Jagiełło, Zofia Holszańska, dynastia jagiellońska, plotka polityczna, niewierność małżeńska.
Abstract: The election and coronation of Władysław Jagiełło as king of Poland in 1386 provided an opportunity for the emergence of a new significant dynasty in Central-Eastern Europe. This fact produced unrest among neighbours (the Luxembourg dynasty and the Teutonic Knights) intent on weakening the Polish-Lithuanian monarchy. Attempts at establishing principles for the enthronement of successive rulers and the range of their prerogatives activated also Polish magnates, who aimed at exerting the greatest possible impact upon state governance. Conflicts appearing against this background made use of assorted methods of a political confrontation, including the political rumour.

Keywords: Wladyslaw Jagiello, Sophia of Halshany, Jagiellon dynasty, political rumour, infidelity.

Skandal dotyczący rzekomej niewierności małżeńskiej królowej Zofii Holszańskiej przyciąga uwagę historyków od wielu pokoleń. Jak stwierdziła już Ewa Maleczyńska, „proces królowej Sonki jest tym epizodem z jej życia, któremu literatura najwięcej, jak dotąd, poświęciła 
miejsca"1. Wspominano o nim zarówno przy okazji omawiania dziejów politycznych Polski, jak również podczas przedstawiania biogramów osób zamieszanych w tę historię $e^{2}$.

Wiadomości związane z oskarżeniem królowej Zofii znane są głównie dzięki relacji Jana Długosza ${ }^{3}$. Telegraficzny skrót, jaki zastosował kanonik krakowski, opisując wydarzenia poprzedzające zjazd w Horodle, który wedle jego opinii miał być zwołany właśnie dla wyjaśnienia tej sprawy, powoduje, iż przekaz ów pomija wiele ważnych szczegółów (także politycznych) mających niewątpliwy wpływ na ocenę tej niecodziennej sytuacji. Przypomnijmy: Długosz jednym zdaniem informuje o śmierci królewicza Kazimierza, w drugim pisze o wielkim zasmuceniu rodziców, a już w następnym o plotkach docierających do księcia Witolda w związku z kolejną ciążą królowej i podejrzeniach, że jest ona wynikiem niewierności małżeńskiej. Wedle kronikarza, z tego właśnie powodu, wielki książę nakłonił Jagiełłę do spotkania w Horodle, gdzie miano ustalić, jakie działania należy podjąć, aby zapobiec szerzeniu się tych plotek. Kolejny, bardzo obszerny fragment Roczników to relacja Długosza z tego zjazdu.

Tymczasem te graniczne epizody (śmierć Kazimierza - spotkanie w Horodle) dzieli przecież okres kilku miesięcy, w czasie których miały miejsce inne, zdecydowanie ważniejsze dla funkcjonowania państwa wydarzenia. Co więcej - wiarygodność relacji Długosza została już podważona nie tylko w odniesieniu do terminu odbycia spotkania w Horodle. Dzięki listowi wielkiego księcia do panów polskich zwrócono uwagę, że Witold w sposób jednoznaczny i stanowczy stanął w obronie królowej, w świetle czego bardzo wątpliwe jest, aby to on - jak chce Długosz - był jej oskarżycielem, domagając się ponadto surowego, natychmiastowego ukarania ${ }^{4}$.

${ }^{1}$ E. Maleczyńska, Rola polityczna królowej Zofii Holszańskiej na tle walki stronnictw w Polsce w latach 1422-1434, Lwów 1936, s. 67.

${ }^{2}$ Z najnowszych prac zob.: B. Czwojdrak, Zofia Holszańska. Studium o dworze i roli królowej w późnośredniowiecznej Polsce, Warszawa 2012, s. 29-33; J. Nikodem, Witold. Wielki ksiązę litewski (1354 lub 1355 - 27 października 1430), Kraków 2013, s. 371 nn. Ustalenia poczynione podczas pracy nad tym artykułem zostały wykorzystane w monografii: W. Zawitkowska, Walka polityczno-prawna o następstwo tronu po Władysławie Jagielle w latach 1424-1434, Rzeszów 2015, zwłaszcza s. 142 nn.

3 Joannis Dlugossii Annales seu Cronicae incliti Regni Poloniae, lib. 11: 1412-1430, Varsaviae 2000 (dalej: Annales XI), s. 226-229.

${ }^{4}$ Rozbiór krytyczny Annalium Poloniae Jana Długosza z lat 1385-1444, t. 1, oprac. S. Gawęda i in. pod kier. J. Dąbrowskiego, Wrocław 1961 (dalej: Rozbiór), s. 228-229. Zob. też: Liber cancellariae Stanislai Ciołek. Ein Formelbuch der polnischen Königskanzlei aus der Zeit der hussitischen Bewegung, wyd. J. Caro, t. 1-2, Wien 1871-1874 (dalej: LC) 1, nr 83, s. 156-157; Codex epistolaris Vitoldi magni ducis Lithuaniae 1376-1430, wyd. A. Prochaska, Kraków 1882 (dalej: CV) nr 1301, s. 782-783 (regest). Szerzej o tym liście w dalszej 
Ubóstwo i niejednoznaczność źródeł - to zapewne powody niepodjęcia do tej pory próby dokładnej rekonstrukcji przebiegu wydarzeń $\mathrm{z}$ tego okresu, co m.in. przekłada się na funkcjonowanie w literaturze przedmiotu różnych opinii na temat przyczyn wybuchu skandalu i jego skutków. Przykładowo: za sprawców niemałego przecież zawirowania społeczno-politycznego uznaje się w historiografii (osobno lub w różnych konfiguracjach) wielkiego księcia litewskiego Witolda ${ }^{5}$, biskupa krakowskiego Zbigniewa Oleśnickiego jako przywódcę ówczesnej opozycji ${ }^{6}$, króla węgierskiego Zygmunta Luksemburskiego ${ }^{7}, \mathrm{Krzyżaków}^{8}$, Hohenzollernów ${ }^{9}$, a nawet mało znanego Jana Strasza z Białaczowa ${ }^{10}$. W wyżej

części artykułu, gdzie przedstawione zostaną również argumenty podważające inne aspekty relacji Długosza.

${ }^{5}$ Np.: G. Błaszczyk, Dzieje stosunków polsko-litewskich, t. 2: Od Krewa do Lublina, Poznań 2007, s. 508-509. W podobnym tonie ostatnio wypowiedział się również Jarosław Nikodem, op. cit., s. 375 nn. Od razu zastrzec należy, że autor choć bardzo ostrożnie szafujący jednoznacznymi sądami, wskazując na odegranie w tej sprawie negatywnej roli przez wielkiego księcia Witolda, oparł się jednak na błędnym założeniu, iż dokument z 13 czerwca 1427 r. wydany w Krakowie dotyczył zamku w Kamieńcu Podolskim, zob. Codex epistolaris saeculi decimi quinti, t. 1, wyd. A. Sokołowski, J. Szujski, Kraków 1876 (dalej: CE 1), nr 68, s. 66. Tymczasem akt ten odnosi się do zamku Kamieniec w Odrzykoniu na Rusi i wydarzeń związanych z buntem szlachty ruskiej w 1426 r., zob. J. Kurtyka, $Z$ dziejów walki szlachty ruskiej o równouprawnienie: represje lat 1426-1427 i sejmiki roku 1439, RH 66, 2000, s. 91. O tym dokumencie zob. też w dalszej części artykułu.

${ }^{6}$ Np. E. Maleczyńska, op. cit., s. 67-69. Na przedstawicieli opozycji (bez imiennego wymienienia) wskazano w: J. Krzyżaniakowa, J. Ochmański, Władysław II Jagiełło, Wrocław 1990, s. 285. Rolę „wykonawczą” opozycji podkreśliła też Anna Sochacka, Jan z Czyżowa, namiestnik Władysława Warneńczyka. Kariera rodziny Półkozów w średniowieczu, Lublin 1993, s. 53. O przeciwnikach małżeństwa Jagiełły i Zofii, którzy przyczynili się do powstania plotek (w tym Oleśnickim) pisała również Bożena Czwojdrak, Rogowscy herbu Działosza. Podskarbiowie królewscy. Studium z dziejów możnowładztwa $w$ drugiej połowie XIV i w XV wieku, Katowice 2002, s. 57-58.

${ }^{7}$ K. Pieradzka, Wstęp, w: Rozbiór, s. XXXVIII; eadem, Związki Długosza z Krakowem, Kraków 1975, s. 72. Na inspirację ze strony Luksemburczyka zwróciła uwagę już E. Maleczyńska, Społeczeństwo polskie pierwszej połowy XV wieku wobec zagadnień zachodnich (studia nad dynastyczna polityka Jagiellonów), Wrocław 1947, s. 122.

8 A. Prochaska, Ostatnie lata Witołda. Studium z dziejów intrygi politycznej, Warszawa 1882, s. 89-93. Ich rolę inspiracyjną (wspólnie z Zygmuntem Luksemburskim) uznaje też A. Sochacka, op. cit., s. 53. Interesy Krzyżaków (i Hohenzollernów) podkreśla także Maria Koczerska, Królowa Zofia Holszańska - jej osobowość i rola polityczna, w: Kobiety o kobietach. Studia i szkice. Średniowiecze i czasy nowożytne, red. W. Zawitkowska, Rzeszów 2010, s. 84.

${ }^{9}$ J. Tęgowski, Stosunek Zbigniewa Oleśnickiego do unii Polski z Litwa, w: Zbigniew Oleśnicki. Ksiażę Kościoła i mąż stanu. Materiały z konferencji, Sandomierz, 20-21 maja 2005 roku, red. F. Kiryk, Z. Noga, Kraków 2006, s. 76.

10 A. Prochaska, Król Władysław Jagiełło, t. 2, Kraków 1908, dodatek 2, s. 400-401. 
wymienionych pracach podnoszono przeważnie motywy polityczne tych oskarżeń, choć zwolenników ma też hipoteza wskazująca jedynie na aspekt obyczajowy skandalu ${ }^{11}$.

Niewykorzystany dotąd w historiografii wypis z ksiąg rachunkowych miasta Lwowa (o czym w dalszej części artykułu) oraz życzliwa uwaga Jarosława Nikodema ${ }^{12}$ skłoniły mnie do podjęcia próby dokonania szczegółowej rekonstrukcji wydarzeń, w nadziei, że powinno to przynieść również odpowiedź na pytanie o przyczyny i skutki oskarżeń rzuconych pod adresem królowej Zofii oraz pozwolić na bardziej szczegółową ocenę wiarygodności przekazu Długosza.

Odtwarzanie przebiegu wydarzeń należy zacząć już od 2 marca 1427 r., kiedy to zmarł drugi z synów pary królewskiej, niespełna roczny Kazimierz. Władysława Jagiełły nie było wówczas w stolicy, znajdował się w drodze z Litwy, gdzie zwyczajowo spędzał zimę. Wedle Długosza w okresie zapustów (ok. 2 marca) przebywał w Chełmie. Tymczasem, w świetle innych źródeł, 21 lutego oraz 2 i 10 marca był w Lublinie. Tam więc (lub w niedalekiej odległości, może nawet w Chełmie oddalonym o ok. $70 \mathrm{~km}$, gdzie mógł przebywać przed lub po 2 marca) dowiedział się o śmierci syna. Jego dłuższy pobyt na Lubelszczyźnie zdaje się wykluczać możliwość wzięcia udziału w uroczystościach pogrzebowych królewicza $^{13}$. Wiele wskazuje bowiem na to, że dopiero po 10 marca opuścił tamte rejony. Kolejny pobyt Jagiełły jest potwierdzony w Nowym Mieście Korczynie, gdzie przebywał z pewnością od 26 do 31 tego miesiąca ${ }^{14}$.

11 Ibidem, zwłaszcza s. 401-402; J. Sperka, Szafrańcowie herbu Stary Koń. Z dziejów kariery i awansu w późnośredniowiecznej Polsce, Katowice 2001, s. 175-177, 203-204; B. Czwojdrak, Zofia Holszańska, s. 29-33 (zob. też wcześniejsze prace tej autorki wymienione w niniejszym artykule). Do tej hipotezy skłaniałam się również i ja, zob. W. Zawitkowska, W służbie pierwszych Jagiellonów. Życie i działalność Jana Taszki Koniecpolskiego, Kraków 2005, s. 122-125, co niniejszym artykułem koryguję.

$12 \mathrm{~J}$. Nikodem, w recenzji mojej pracy $W$ służbie pierwszych, słusznie wskazał, że kwestię tę potraktowałam „dość lakonicznie, jak na wagę wydarzenia” (St. Źr. 47, 2009, s. 245), za co w tym miejscu dziękuję.

13 Annales XI, s. 226; A. Gąsiorowski, Itinerarium króla Władysława Jagiełty 1386-1434, wyd. 2 popr. i uzup., oprac. A. Gąsiorowski, G. Rutkowska, Warszawa 2015, s. 109; W. Zawitkowska, Walka polityczno-prawna, s. 142. Możliwe, że Jagiełło spotkał się wówczas z Witoldem, aby omówić kwestie dotyczące szlachty ruskiej, zob. list Stanisława Ciołka do wielkiego księcia (Kraków, 6 II 1427): LC 1, nr 102, s. 180-181 = CV, nr 1267, s. 756 (regest); W. Zawitkowska, Walka polityczno-prawna, s. 142-143. Nie wyklucza tego itinerarium Witolda, wedle którego 17 marca wielki książę był w Dubiczu, a 6 kwietnia w Brześciu Litewskim: J. Purc, Itinerarium Witolda wielkiego księcia litewskiego (17 lutego 1370 roku - 27 października 1430 roku), „Zeszyty Naukowe Uniwersytetu im. Adama Mickiewicza w Poznaniu", nr 74, Historia, z. 11, 1971, s. 104.

${ }^{14}$ A. Gąsiorowski, op. cit., s. 109; CV, nr 1273, s. 762 (ceduła listu Władysława Jagiełły 
Źródła nie podają informacji, gdzie początek roku spędzała królowa Zofia. Wprawdzie w Rocznikach Długosza pod koniec 1426 r. jest napisane, iż Jagiełło, gdy polował na Litwie, miał zwyczaj posyłania dziczyzny królowej oraz możnym duchownym, świeckim, książętom śląskim, profesorom Uniwersytetu w Krakowie, a nawet stołecznym rajcom, jest to jednak informacja zbyt ogólnikowa, aby na jej podstawie wyrokować, iż właśnie tej zimy przekazywał upolowaną zwierzynę Zofii, co z kolei mogłoby wskazywać, że pozostawała w Krakowie i była świadkiem śmierci młodszego ze swoich synów oraz uczestniczyła w jego pogrzebie ${ }^{15}$. Warto w tym kontekście zwrócić jednak uwagę na fakt, iż z Nowego Miasta Korczyna król udał się przez Proszowice (2 kwietnia) do Niepołomic (3-5 t.m.). W Podwodach kazimierskich znajduje się ponadto zapiska, że 3 kwietnia właśnie w kierunku Niepołomic przewożone były rzeczy królewny Jadwigi i królewicza Władysława ${ }^{16}$. Brak informacji o podwodach udzielonych dla królowej może wskazywać, że Zofia wyjechała na spotkanie z mężem zaraz po pogrzebie syna i z dużą dozą prawdopodobieństwa była u jego boku w Nowym Mieście Korczynie (oddalonym od Krakowa tylko ok. $75 \mathrm{~km}$ ). Wskazuje na to również pośrednio termin narodzin kolejnego syna pary monarszej - Kazimierza Andrzeja (30 XI 1427). „Podręcznikowy” czas trwania ciąży to 38 tygodni od poczęcia, zatem powinno ono mieć miejsce ok. 10 marca lub w ciągu najbliższych dwu tygodni, przyjmując oczywiście, iż poród nie był przedwczesny ${ }^{17}$.

Po wysoce prawdopodobnym, choć krótkim pobycie wraz z żoną i dziećmi w Niepołomicach król udał się ponownie w podróż - tym razem na Ruś, docelowo do Halicza, gdzie pod koniec czerwca był zaplanowany hołd szlachty ruskiej. Zapewne już 6, a z pewnością 7 i 8 kwietnia był w Bochni (planował tam pobyt do 9 t.m.), a od 11 do 12 t.m. w Bieczu ${ }^{18}$.

do Witolda). Pobyt w tym miejscu jest typowy dla itinerarium władcy, który zwyczajowo na śródpoście zjeżdżał w pobliże stolicy i tam pozostawał przez dłuższy czas.

15 Annales XI, s. 222; G. Rutkowska, Itineraria żon króla Władysława Jagiełty, RH 64, 1998, s. 80; B. Czwojdrak, Zofia Holszańska, s. 29.

${ }^{16}$ Podwody kazimierskie 1407-1432, wyd. S. Krzyżanowski, „Archiwum Komisji Historycznej Akademii Umiejętności”, t. 11, 1909-1913 (dalej: PK), s. 432.

17 Królowa wielokrotnie wyjeżdżała na spotkanie małżonka powracającego z objazdu Litwy lub witała go w swych dobrach oprawnych - Nowym Korczynie, zob. G. Rutkowska, op. cit., passim; W. Zawitkowska, Walka polityczno-prawna, passim, np. s. 38, 144.

Ta propozycja koryguje nieco termin poczęcia Kazimierza wyznaczony przez Grażynę Rutkowską, zob. op. cit., s. 80. Warto w tym miejscu zwrócić uwagę na okres roku liturgicznego, w jakim to miało miejsce, a był to mianowicie czas Wielkiego Postu (Środa Popielcowa wypadała 5 III 1427, Wielkanoc dość późno, bo 20 kwietnia).

${ }^{18}$ A. Gąsiorowski, op. cit., s. 109; P. Węcowski, Działalność publiczna możno- 
Zofia nie towarzyszyła mężowi w początkowym etapie podróży. W dniach od 14 do 19 kwietnia w Podwodach kazimierskich odnotowano przejazd dworzan królowej udających się z jej polecenia z listami do Jagiełły $^{19}$. To bardzo częste przesyłanie korespondencji nie jest w świetle zachowanych źródeł standardowe, wskazuje na pewną niezwykłość i wyjątkowość sytuacji.

Nie można wykluczyć, że wymiana informacji między małżonkami związana była z planowaną najpewniej już wcześniej (ze względu na główny cel, czyli hołd) podróżą na Ruś także Holszanki oraz dzieci królewskich (z pewnością Jadwigi) ${ }^{20}$. Tymczasem pamiętać należy, że Sonka w tym czasie była w pierwszych tygodniach ciąży. Możliwe więc, że korespondencja związana była np. z przesuwaniem terminu wyruszenia orszaku królowej z Krakowa lub zmianą trasy podróży. Nie wiadomo, jak Zofia znosiła początek kolejnej, i to w tak krótkim czasie, ciąży. Późniejsza obecność u jej boku lekarza - dowodnie potwierdzona we Lwowie (zob. w dalszej części artykułu), może wskazywać na ewentualne kłopoty zdrowotne czy niedogodności charakterystyczne dla pierwszego trymestru. A podróż małżonków na Ruś nie wynikała przecież z chęci odbycia wspólnej podróży, ale przede wszystkim z kalkulacji politycznych, a niespodziewana (choć bardzo pożądana zwłaszcza po śmierci Kazimierza) ciąża królowej mogła te plany modyfikować lub opóźniać. W tym kontekście - czego nie należy wykluczać - bardzo interesującą pod względem obyczajowym byłaby hipoteza, że dopiero właśnie w jednym z listów Zofia poinformowała o swoim odmiennym stanie męża, bo nie ma pewności (ze względu na krótki czas od poczęcia), że dowiedział się o tym przed wyjazdem z Niepołomic ${ }^{21}$.

władztwa małopolskiego w późnym średniowieczu. Itineraria kasztelanów $i$ wojewodów krakowskich w czasach panowania Władysława Jagiełły (1386-1434), Warszawa 1998, s. 184; J. Tęgowski, Kilka uzupełnień do itinerarium króla Władysława Jagiełły, St. Źr. 41, 2003, s. 85.

19 PK, s. 432: 14 kwietnia - Paweł Szczukowski łożny; 16 kwietnia - Piotr łożny; 17 kwietnia - Mikołaj Zielonka „procurator alias szapharz”; 19 kwietnia - Mikołaj Przepiórka łożny. Ich biogramy i działalność zob. B. Czwojdrak, Zofia Holszańska, wg indeksu. W tym czasie odnotowano także dwukrotny przejazd innych osób z różnymi rzeczami dla króla.

${ }^{20} \mathrm{Na}$ zasadzie analogii można wskazać na objazd Wielkopolski w 1425 r. (G. Rutkowska, op. cit., s. 84 nn., zwłaszcza s. 87-88) oraz prawdopodobną dłuższą wspólną podróż pary królewskiej tamże w 1424 r. (W. Zawitkowska, Walka polityczno-prawna, s. 51-53). O uczestnictwie w objeździe Rusi w 1427 r. królewny Jadwigi zob. w dalszej części artykułu.

${ }^{21}$ Wśród czterech posłańców z listami trzech to pokojowcy, czwarty zaś był szafarzem królowej, zob. przyp. 19. 
Oprócz listów Zofii posłańcy mogli jeszcze przekazywać korespondencję dostarczaną do Krakowa np. przez wysłanników papieża ${ }^{22}$, Witolda czy Zygmunta Luksemburskiego ${ }^{23}$. Niewykluczone, że właśnie wówczas przesłano Jagielle list od Zygmunta w sprawie nowego terminu zjazdu dotyczącego rozgraniczeń między Nową Marchią a Polską, w którym - co należy szczególnie podkreślić - Luksemburczyk zanim napisał o kwestii krzyżackiej, to nie tylko złożył królowi kondolencje z powodu śmierci syna, ale zamieścił również gratulacje związane z kolejną ciążą Zofii ${ }^{24}$.

W tym kontekście należy podkreślić, że plotki o rzekomej niewierności królowej i oskarżeniem w związku z tym aż siedmiu rycerzy nie były raczej znane królowi przed wyruszeniem na Ruśs ${ }^{25}$. Na dokumentach wystawionych w Bieczu w formule relacji występują: Jan Kraska oraz Wawrzyniec

${ }^{22}$ Listy te dotyczyły przede wszystkim bardzo długiego sporu o obsadzenie biskupstwa poznańskiego, zob. Z. Kowalska, Stanisław Ciołek (zm. 1437). Podkanclerzy królewski, biskup poznański, poeta dworski, Kraków 1993, s. 64 nn.

${ }^{23}$ Pod koniec marca i na początku kwietnia Jagiełło prowadził dość ożywioną korespondencję z Witoldem i Zygmuntem Luksemburskim w sprawie przesunięcia pierwotnie ustalonego na 4 maja terminu zjazdu dotyczącego spraw granicznych między Nową Marchią a Wielkopolską. List z propozycją nowej daty na św. Urbana (25 maja), wysłany z Nowego Miasta Korczyna 31 marca, dotarł do Witolda już 4 kwietnia, zob. CV, nr 1273, s. 761-762. Z jego treści wynika, że Jagiełło w tej samej sprawie napisał też do Zygmunta - zatem należy mniemać, że oba listy wyszły z kancelarii królewskiej w tym samym czasie. Nie wiadomo dokładnie, kiedy list w sprawie udziału w tym właśnie zjeździe otrzymał król rzymski, z pewnością jednak nie tak szybko jak Witold - por. itinerarium Luksemburczyka: P. Engel, Itinerarium Sigismundi regis imperatorisque (1382-1437), w: Itineraria regum et reginarum (1382-1438), wyd. N.C. Tóth, Budapest 2005, s. 121.

${ }^{24}$ List Luksemburczyka (CV, nr 1272, s. 760) nie ma daty. Pełnomocnictwo na ten zjazd dla polskich przedstawicieli, nota bene uwzględniające udział wysłanników Zygmunta, zostało wystawione przez króla Jagiełłę w Medyce 5 maja - zob. Codex epistolaris saeculi decimi quinti, t. 2, wyd. A. Lewicki, Kraków 1891 (dalej: CE 2), nr 157, s. 203-204 = CV, nr 1284, s. 769-770. O śmierci Kazimierza Zygmunt dowiedział się najpewniej drogą oficjalną, może z listu Jagiełły (zob. przypis wyżej). Natomiast tak szybko o kolejnej ciąży Holszanki mógł zostać poinformowany przez zaufanych ludzi przebywających w otoczeniu dworu królewskiego. Świadczyłoby to z pewnością bardzo dobrze o funkcjonowaniu wywiadu Zygmunta Luksemburczyka na dworze polskim. Na temat szpiegów i agentów działających w otoczeniu władców i w stolicach państw zob. np. interesującą pracę Sławomira Jóźwiaka, Na tropie średniowiecznych szpiegów. Wywiad i kontrwywiad w polsko-litewsko-krzyżackich stosunkach politycznych w XIV i pierwszej połowie XV wieku, Inowrocław 2005. O tymże liście wspominał już Antoni Prochaska (Król Władysław, s. 402), błędnie uznając jednak, iż powstał on dopiero latem $1427 \mathrm{r}$.

${ }^{25}$ Co oczywiście nie wyklucza, że jakieś plotki mogły się już wówczas pojawiać w bliskim otoczeniu dworu. Była to przecież kolejna (trzecia) ciąża królowej w tak krótkim czasie, a do poczęcia doszło zaraz po śmierci drugiego syna. Por. B. Czwojdrak, Zofia Holszańska s. 29, przyp. 104. 
Zaremba ${ }^{26}$. Jednym z posłów odnotowanych w Podwodach kazimierskich był z kolei Paweł Szczukowski, prawdopodobnie brat obu dwórek królowej poddanych potem rzekomo torturom, a z pewnością odesłanych na Litwę ${ }^{27}$.

Dłuższy postój króla odnotowany jest w Medyce - od 28 kwietnia do 5 maja ${ }^{28}$. Na możliwy pobyt Zofii u boku męża właśnie w tym miejscu wskazała już Grażyna Rutkowska. Z 1 maja pochodzi bowiem wydany tam dokument Jagiełły, na którym z tytułem ochmistrza królowej i podkomorzego łęczyckiego świadkował Wojciech Malski ${ }^{29}$. To przypuszczenie jest słuszne, zwłaszcza że obecność królowej oraz królewny Jadwigi potwierdzona jest źródłowo na dalszym etapie podróży - we Lwowie. Zgodnie z wypisami poczynionymi przez Dionizego Zubrzyckiego z zaginionej dziś miejskiej księgi rachunkowej z lat 1414-1459 ${ }^{30}$ wiadomo, że król wraz z całym dworem był we Lwowie i tam 14 maja wydał kolejny przywilej dla mieszczan ${ }^{31}$. W czasie tego pobytu (brak dokładnej daty, a obecność Jagiełły jest tam potwierdzona do 20 maja) „złożono królowi w darze iakoś materyą iedwabną «stanum sericeum longum atque nigrum Custori»? nazwaną za 10 kóp. Królowey dwa postawy materyi za

${ }^{26}$ KDM 4, nr 1245; Zbiór dokumentów małopolskich, cz. 7, wyd. I. Sułkowska-Kuraś, S. Kuraś, Wrocław 1975 (dalej: ZDM 7), nr 2005, s. 219.

${ }^{27}$ PK, s. 432. Jego biogram zob. B. Czwojdrak, Zofia Holszańska, s. 168. W uzupełnieniu należy dodać, że przywiesił on swoją pieczęć na dokumencie szlachty podolskiej (akcie kamienieckim) z 1439 r., zob. szerzej J. Kurtyka, op. cit., Aneks 2, s. 111-119.

28 A. Gąsiorowski, op. cit., s. 109.

${ }^{29}$ KDW 9, nr 1128; G. Rutkowska, op. cit., s. 81. Po dokładnej analizie trasy przejazdu Jagiełły można pokusić się o przypuszczenie, że do spotkania władcy z żoną i córką doszło jeszcze wcześniej niż w Medyce. Król, którego pobyt w Przemyślu Długosz odnotowuje 20 kwietnia, cztery dni później - jak wynika z innego źródła - był w Jarosławiu. Jeżeli przyjmiemy, że na Ruś udawał się trasą nie przez Pilzno i Ropczyce, lecz „drogą południową” przez Sanok (na co może wskazywać fakt, iż z Bochni pojechał do Biecza), to zastanawiać może, w jakim celu w Przemyślu zmienił kierunek podróży i cofnął się. Racjonalnym wytłumaczeniem byłby fakt, iż pojechał do Jarosławia na spotkanie królowej i królewny (podróż królowej trasą przez Pilzno i Ropczyce mogłaby wynikać np. z chęci uniknięcia przejazdu w górzystym terenie, właśnie ze względu na odmienny stan) i stamtąd już razem dotarli do Medyki. Nie można jednakże wykluczyć ponownej pomyłki Długosza, tym razem w podaniu daty pobytu króla w Przemyślu, gdzie Jagiełło mógł być po 20 kwietnia, a nie dokładnie tego dnia. Zwrócić należy bowiem uwagę, że z Biecza mógł skierować się w stronę Pilzna, 24 kwietnia przebywać w Jarosławiu, następnie zaś przez Przemyśl (26, 27 kwietnia?) dotrzeć do Medyki.

30 Zob. K. Badecki, Zaginione księgi średniowiecznego Lwowa. Studium rekonstrukcyjne, Lwów 1927, zwłaszcza s. 33-51.

31 AGZ 5, nr 91, s. 55-56. D. Zubrzycki (Kronika miasta Lwowa, Lwów 1844, s. 92) podał nawet dokładną sygnaturę tego przywileju (,fasc. 281, nr 5”). Obecnie nie ma go w Centralnym Państwowym Archiwum Historycznym Ukrainy we Lwowie (Центральний державний історичний архів України, м. Львів - ЦДІАЛ України). 
7 kóp, a królewnie iedne za 4 kopy - Kanclerzowi Janowi Szafrancowi takoż samą, kamień pieprzu za 3 kopy i ieden ferton (ferdung) i beczkę piwa za 48 groszy. Wicekanclerzowi podobnież, oprócz piwa - Doktorowi królewskiemu iedne sztukę, a marszałkowi kamień pieprzu"32.

W zapisce przytoczonej przez D. Zubrzyckiego warto zwrócić uwage na rzadki fakt obdarowania prezentem przez mieszczan osoby nie sprawującej urzędu, mianowicie królewskiego lekarza ${ }^{33}$. Z kolei brak informacji o podarkach dla królewicza Władysława wskazuje, że pozostał najpewniej w stolicy (lub w pobliżu - Nowe Miasto Korczyn?). Gdyby był we Lwowie, to z pewnością otrzymałby prezent, podobnie jak przyrodnia siostra. Dość długa podróż tak małego dziecka (2,5 roku), zwłaszcza po niedawnej śmierci brata, nie była wskazana ${ }^{34}$.

Względy chronologiczne pozwalają ponadto wysunąć przypuszczenie, że w okresie dłuższego pobytu we Lwowie przygotowane zostały kolejne już listy kierowane do papieża przez króla i królową w sprawie biskupstwa dla Stanisława Ciołka, co potwierdza uczestnictwo Zofii w bieżących wydarzeniach politycznych. Na brak konfliktu między małżonkami w tym czasie wskazuje również fakt, iż najpewniej wówczas oboje zwracali się do Marcina V z prośbą o potwierdzenie na godności kustosza kapituły gnieźnieńskiej kuzyna Zofii - Hermana Giedroycia ${ }^{35}$.

Potwierdzona źródłowo obecność Zofii we Lwowie może z dużym prawdopodobieństwem sugerować, iż królowa towarzyszyła małżonkowi w dalszym objeździe i razem z nim oraz z królewną Jadwigą odbierała pod koniec czerwca hołd ziem ruskich w Haliczu. Pobyt króla jest tam udokumentowany na pismach wydanych w dniach od 24 do 29 czerwca. Akty homagialne ziem lwowskiej, halickiej, przemyskiej, sanockiej, trembowelskiej oraz powiatów śniatyńskiego i kołomyjskiego wystawiane były

32 D. Zubrzycki, op. cit., s. 92-93; W. Zawitkowska, Walka polityczno-prawna, s. 145146. Tak hojne dary były więc również podziękowaniem za otrzymany przywilej.

33 W PK (s. 433) odnotowano pod datą 12 maja przejazd lekarza królewskiego mistrza Jakuba (przygotowano wówczas aż 5 koni). Niewykluczone więc, że obdarowanym lekarzem był właśnie ów mistrz Jakub.

${ }^{34}$ Pozostawianie dzieci królewskich nawet na dłuższy czas tylko pod opieką opiekunek (wychowawczyń) było w tym czasie rzeczą naturalną. Zob. np. przekaz Długosza informujący o wyjeździe pary królewskiej w 1425 r. na Litwę przed szalejącą zarazą, podczas gdy małego Władysława wywieziono „jedynie” do zamku w Chęcinach (Annales XI, s. 214).

${ }^{35}$ CV, nr 1278-1279, 1281, s. 765-768. Chronologię listu Zofii w sprawie S. Ciołka, w stosunku do propozycji wydawcy, który umieścił go w początkach maja, poprawiła już, choć również bez komentarza, Zofia Kowalska, op. cit., s. 69. Pisma te powstały, zanim do rąk króla dotarł list papieża, który wiózł (wraz z korespondencją do Witolda) posłaniec odnotowany w PK pod datą 26 maja, zob. ibidem, s. 433. 
natomiast 28 i 29 t.m. Ze względu na znaczenie tych wydarzeń dziwi fakt nieuwzględnienia ich w relacji Długosza ${ }^{36}$.

Dopiero zatem na początku lipca król z królową wyruszyli w drogę powrotną do Korony. Zgodnie z itinerarium sporządzonym przez Antoniego Gąsiorowskiego obecność Jagiełły potwierdzona jest w Drohobyczu (8 lipca), Oziminie (9-10 lipca), Przemyślu (20-22 lipca) i Medyce (22 lip$\mathrm{ca}^{37}$. Z uwagi na trasę przejazdu niewykluczone jest, że do rozdzielenia dworów doszło w Przemyślu, skąd Zofia mogła udać się w dalszą podróż, Władysław zaś ze swym otoczeniem zawrócił do Medyki (ze względów aprowizacyjnych lub z powodu sentymentu do tego miejsca). Możliwe jednak, że para królewska wspólnie pojechała do Medyki, spędzając kilka dni w ulubionym dworze Jagiełły, nie zaś w starościńskim zamku.

Po objeździe ziem ruskich, najpewniej przez Łańcut ${ }^{38}$, król udał się do Wiślicy, gdzie jego pobyt jest potwierdzony od 16 do 26 sierpnia $^{39}$. Tam właśnie, a nie w Nowym Mieście Korczynie, jak pierwotnie zakładano ${ }^{40}$,

${ }^{36}$ Z Jana Zamoyskiego Inwentarza Archiwum Koronnego. Materiały do dziejów Rusi i Litwy w XV wieku, oprac. O. Halecki, „Archiwum Komisji Historycznej Akademii Umiejętności”, t. 12, cz. 1, 1919, s. 179-193; Z. Spieralski, Z dziejów Archiwum Koronnego Krakowskiego. Kopiariusz Jana Łaskiego (około 1505), St. Źr. 24, 1979, s. 129-133, nr 28-34; J. Kurtyka, op. cit., s. 83-119; A. Gąsiorowski, op. cit., s. 109; W. Zawitkowska, Walka polityczno-prawna, s. 146-148. Takie przypuszczenie wysunęła już G. Rutkowska, op. cit., s. 81. O pobycie na Rusi pisała też (ale bez podania źródeł) E. Maleczyńska, Rola polityczna, s. 66-67.

37 A. Gąsiorowski, op. cit., s. 109-110.

38 Datacja listu S. Ciołka do wielkiego księcia Witolda (Łańcut, 29 lipca) - zob. LC 1, nr 108-109, s. 193-194 = CV, nr 1294, s. 775-776 (regest) - jest niepewna. Już Z. Kowalska (op. cit., s. 69-70), choć nie wyjaśniła powodów emendacji, to omawiając przebieg konfliktu między Marcinem V a Jagiełłą, umieściła to pismo przed listem Witolda do papieża i kolegium kardynalskiego, datowanym zarówno przez nią, jak i przez A. Prochaskę na maj i pisanym właśnie w obronie Ciołka, zob. LC 1, nr 107-108, s. 189-192 = CV, nr 1285, s. 770 (regest). Analizując treść, można rzeczywiście z bardzo dużym prawdopodobieństwem przyjąć, iż list S. Ciołka powstał w Łańcucie pod koniec kwietnia. Za tą datą przemawia również fakt, iż odpowiedź papieża do Witolda (i osobno do Jagiełły) nosi datę 6 czerwca, zob. CE 2, nr 158, s. 204; nr 159, s. 205. Po odpowiedzi z czerwca nie było bowiem powodu, aby ponownie interweniować u Witolda $\mathrm{z}$ prośbą o wstawiennictwo u papieża. To z kolei mogłoby potwierdzać fakt, że w kwietniu król z Biecza udał się najpierw do Pilzna i stąd podążył na Ruś przez Łańcut, Jarosław, Przemyśl (zob. przyp. 29).

39 A. Gąsiorowski, op. cit., s. 110.

40 O planowanym zjeździe w Nowym Mieście Korczynie zob. list komtura toruńskiego do wielkiego mistrza, Toruń, 26 VII 1427: CV, nr 1293, s. 775 (tam informacja o terminie rozpoczęcia - 15 sierpnia). Zmiana miejsca nie wzbudza zastrzeżeń - Wiślicę od Nowego Miasta Korczyna dzieli wszak tylko kilkanaście kilometrów. Mogła być ona spowodowana faktem, iż w Nowym Mieście Korczynie prawdopodobnie przebywała Zofia oraz Jadwiga i Władysław junior, a każde z nich posiadało własny dwór (zob. szerzej w dalszej 
odbył się zjazd generalny, na którym z pewnością byli obecni najwyżsi dostojnicy Królestwa ${ }^{41}$. Z uwagi na to, że jest to jedyna znana dotąd informacja o uczestnikach tego zjazdu, oraz wobec niejednoznacznych i często ogólnikowych sformułowań używanych w źródłach dla zgromadzeń z tego okresu ${ }^{42}$ można jednak przypuszczać, że był to sejm, w którym wzięła udział szlachta nie tylko z Małopolski, przybywająca tam regularnie w drugiej połowie sierpnia ze względu na zwyczajowy pobyt króla. Dla Wielkopolan był on szczególnie ważny zarówno z uwagi na sytuację na pograniczu, gdzie brak porozumienia z Krzyżakami doprowadził nawet do wzrostu nastrojów wojennych i zbrojeń, jak też dlatego, iż w tym roku Jagiełło w czasie, gdy zazwyczaj objeżdżał Wielkopolskę, udał się na Ruś, aby przyjąć hołd miejscowej szlachty ${ }^{43}$. Zjazd generalny (sejm) w Wiślicy byłby jedynym tego typu zgromadzeniem w $1427 \mathrm{r}$.

części artykułu). W świetle przywołanej relacji komtura toruńskiego pomysł zwołania zjazdu narodził się po sejmiku wielkopolskim, na którym omawiano kwestię delimitacji w okolicy Jasińca i Drezdenka. Na inicjatywę wielkopolską w zakresie zwołania zjazdu wskazuje osoba wojewody kujawskiego Macieja z Łabiszyna, który - wg relacji krzyżackiej - miał posłować do króla w sprawie wyrażenia zgody na jego odbycie i uzyskał zapewnienie, że władca przybędzie na obrady. Potwierdzeniem zajęcia się w Wiślicy sprawą ustalenia przebiegu granicy jest list, który Jagiełło wysłał do wielkiego mistrza (z aprobatą terminu kolejnego spotkania) oraz pełnomocnictwo wystawione dla polskich negocjatorów, zob. A. Szweda, Organizacja i technika dyplomacji polskiej w stosunkach z zakonem krzyżackim w Prusach w latach 1386-1454, Toruń 2009, nr 59, s. 400-401; W. Zawitkowska, Walka polityczno-prawna, s. 148 nn. Por. też: A. Gąsiorowski, op. cit., s. 110. Zjazd ten, podobnie jak pobyt pary monarszej na Rusi, został pominięty w relacji Długosza.

41 ,animo deliberato unacum prelatis et baronibus Regni nostri in generali congregacione presenti nobiscum congregatis perpetuo nostro edicto statuimus per presentes, quod", AGZ 9, nr 30, s. 41-42 (19 siepnia). Szerzej zob.: W. Zawitkowska, Walka polityczno-prawna, s. 148, przyp. 21.

${ }^{42}$ Por. np. ogólne uwagi Piotra Węcowskiego (op. cit., s. 82-85), który odnosząc się do omawianego zgromadzenia i przedstawiając kwestię udziału możnowładztwa małopolskiego w zjazdach ogólnopolskich i prowincjonalnych, nie zwrócił uwagi na dokument z 19 sierpnia wydany w Wiślicy (zob. wyżej), lecz jedynie na regest znajdujący się w CV, nr 1293, s. 775, w wyniku czego uznał, że zjazd odbył się w Nowym Mieście Korczynie.

${ }^{43}$ A. Gąsiorowski, op. cit., passim. Nieliczne dokumenty wystawione w Wiślicy oraz te, które zostały sporządzone zaraz po zjeździe w sąsiednim Nowym Mieście Korczynie (zob. niżej), potwierdzają pobyt u boku Jagiełły: arcybiskupa gnieźnieńskiego Wojciecha Jastrzębca, biskupa krakowskiego Oleśnickiego, kasztelana krakowskiego Krystyna z Ostrowa, wojewodów: Jana z Tarnowa - krakowskiego, Mikołaja z Michałowa - sandomierskiego, Jakuba z Koniecpola - sieradzkiego, Marcina z Rytwian - łęczyckiego, kasztelanów: Michała z Bogumiłowic i Czyżowa - sandomierskiego i Jana ze Szczekocin - lubelskiego, kanclerza Jana Szafrańca, podkanclerzego S. Ciołka, marszałka wielkiego koronnego Zaremby, podkomorzego sandomierskiego Andrzeja z Żelechowa, Pawła z Bogumiłowic sędziego i Jakusza z Boturzyna podsędka krakowskiego, Piotra z Fałkowa sędziego i Zawiszę z Oleśnicy podsędka sandomierskiego. 
Z pewnością co najmniej do powrotu króla do Korony i zjazdu w Wiślicy nie doszło do wybuchu skandalu związanego z rzekomą niewiernością królowej Sonki, albowiem na rycerzy oskarżonych w tej sprawie nie zostały nałożone żadne sankcje. Piotr i Dobiesław Szczekoccy byli w Krakowie 13 czerwca, kiedy to świadkowali na dokumencie Stefana (Szczepana) z Bydłowej i innych panów w sprawie zamku Kamieniec (w Odrzykoniu) ${ }^{44}$. Z kolei Zaremba jako marszałek wielki koronny i jeden z sędziów wyznaczonych przez króla w sprawie o wójtostwo trembowelskie, wystawił 27 czerwca w Haliczu dokument w tej kwestii. On również był relatorem aktu Jagiełły z 11 lipca wydanego w Oziminie i świadkował na dyplomie z 21 lipca z Przemyśla. Jego obecność u boku króla w Wiślicy potwierdza też dokument z 19 sierpnia, którego był relatorem ${ }^{45}$.

Najwcześniej więc dopiero po powrocie z Rusi, kiedy ciąża Zofii stała się widoczna, powstała lub mogła zacząć rozprzestrzeniać się plotka o rzekomej niewierności królowej. Zjazd w Wiślicy sprzyjał szybkiemu rozpowszechnianiu się różnych wiadomości. Wiele wskazuje na to, że wykorzystując obecność zarówno Małopolan, jak i Wielkopolan, król mógł podjąć, ciągle otwartą po nieprzyjęciu ustaleń brzeskich na zjeździe w Łęczycy w roku poprzednim, kwestię następstwa tronu. W takim ujęciu, chociażby ze względu na wydźwięk propagandowy, bardzo możliwy jest wówczas pobyt u boku Jagiełły nie tylko Zofii i królewny Jadwigi (powracających z nim z Rusi), ale również pierworodnego Władysława, którzy mogli przebywać np. w położonym nieopodal Nowym Mieście Korczynie. Król, mający na poparcie swych planów dynastycznych bardzo duży sukces w postaci bezwarunkowej zgody szlachty ruskiej na objęcie tronu po jego śmierci przez juniora, liczył zapewne na przyjęcie takiego stanowiska również przez przedstawicieli pozostałych ziem. Jeżeli działania te zostały podjęte, to co najmniej u niektórych zgromadzonych musiały wywołać sprzeciw. Kwestia sukcesji zatem - jak się zdaje - to najbardziej prawdopodobna przyczyna rozprzestrzenienia się plotki o rzekomej niewierności królowej. Była ona obliczona nie tylko na zdyskredytowanie Holszanki jako przykładnej matki i żony, ale przede wszystkim na uderzenie przez oszczerstwa w Zofię jako królową - przewidzianą przecież w planach dworu na współregentkę. Rozpowszechniający plotkę zdawali sobie sprawę, że nie jest raczej możliwe podważenie legalności potomstwa Jagiełły (zwłaszcza Władysława juniora), zapewne

${ }^{44}$ CE 1, nr 68, s. 66. W testacji występują zaraz po staroście krakowskim Mikołaju z Michałowa. O dokumencie zob. szerzej: J. Kurtyka, op. cit., s. 91 nn.

${ }^{45}$ Materiały archiwalne wyjęte głównie z Metryki Litewskiej od 1348 do 1607 roku, wyd. A. Prochaska, Lwów 1890, nr 63, s. 50-51; ZDM 7, nr 2011, 2012; AGZ 9, nr 30; W. Zawitkowska, Walka polityczno-prawna, s. 150. 
też nie to było ich celem. Skupili się przede wszystkim na ośmieszeniu króla, umniejszeniu roli politycznej królowej i zdeprecjonowaniu zwolenników planów dynastycznych ${ }^{46}$. Jak słusznie sugerowały już np. Jadwiga Krzyżaniakowa i Anna Sochacka, to ciężkie oskarżenie wyszło z kręgów opozycji wewnętrznej ${ }^{47}$. Bardzo możliwe, że znaczny udział w powstaniu (lub rozpowszechnianiu) tych oszczerstw miał biskup Oleśnicki ${ }^{48}$. W takim ujęciu plotka na pozór o charakterze obyczajowym (możliwe, że nawet takie było pierwotne podłoże związane z charakterem Zofii i stylem jej zachowania) została wykorzystana (ale nie można wykluczyć, że także wymyślona) w celach politycznych.

Przyjmując hipotezę, iż królowa przebywała w Nowym Mieście Korczynie, można sądzić, że to właśnie tam małżonkowie widzieli się po raz ostatni przed rozwiązaniem. Po dłuższym pobycie w Wiślicy Jagiełło kilka dni spędził bowiem właśnie w dobrach oprawnych żony, gdzie jego obecność potwierdzona jest do 31 sierpnia $^{49}$. Z pewnością wkrótce po tej dacie król wyruszył w stronę Litwy na spotkanie w Horodle z wielkim księciem - 9 września był już w Przyszowie, dwa dni później w Sandomierzu, a 19 t.m. przebywał w Lublinie. 23 września jego obecność odnotowana została w Skokach, a 26 t.m. w Żukowie ${ }^{50}$.

Zjazd z Witoldem w Horodle był już wcześniej zaplanowany i - co należy mocno podkreślić - dotyczyć miał nie tej kwestii, którą podaje Długosz. W liście z 14 sierpnia pisanym w Smoleńsku Kiejstutowicz potwierdził wielkiemu mistrzowi, że właśnie w Horodle spotka się z Jagiełłą i zechce go wówczas przekonać do ostatecznego rozwiązania spraw spornych z zakonem, czyli dotyczących ustalenia granic w okolicach Drezdenka i Jasińca. Ze względu na planowany na 29 września zjazd w Horodle Władysław Jagiełło nakazał dokumentem wydanym w Wiślicy 17 sierpnia zawiesić roki sądowe przeciw arcybiskupowi Wojciechowi Jastrzębcowi. Warto podkreślić, że z tego samego dnia pochodzi list Władysława Jagiełły do wielkiego mistrza dotyczący spotkania pełnomocników obu stron ${ }^{51}$. Bezsprzecznie zatem celem zwołania zjazdu w Horodle nie było rzekomo złe prowadzenie się królowej.

${ }^{46}$ Szerzej zob.: W. Zawitkowska, Walka polityczno-prawna, s. 149 nn.

${ }^{47}$ J. Krzyżaniakowa, J. Ochmański, op. cit., s. 285; A. Sochacka, op. cit., s. 53.

48 W. Zawitkowska, Walka polityczno-prawna, passim, zwłaszcza s. 152-153.

${ }^{49}$ Katalog dokumentów, listów oraz pieczęci królów i królowych polskich przechowywanych w Archiwum Państwowym we Wrocławiu, oprac. M. Chmielewska, Wrocław 1991, nr 33; Zbiór dokumentów małopolskich, cz. 2, wyd. S. Kuraś, Wrocław 1963 (dalej: ZDM 2), nr 392; P. Węcowski, op. cit., s. 184.

50 A. Gąsiorowski, op. cit., s. 110; W. Zawitkowska, Walka polityczno-prawna, s. 154, przyp. 40.

${ }^{51}$ CV, nr 1298, s. 778-780; KDW 9, nr 1134, s. 95-96; A. Gąsiorowski, op. cit., s. 110. 
Nieprawdziwa jest też kolejna informacja Długosza o tym, że w obradach horodelskich nie brała udziału królowa, została bowiem odesłana do Medyki ${ }^{52}$. Pamiętać należy, że najpewniej zaraz po przyjęciu wraz z mężem hołdu ziem ruskich, być może przez Medykę (stąd te informacje Długosza?), wróciła z królem i najprawdopodobniej przebywała w Nowym Mieście Korczynie, a niewykluczone, że wzięła też udział w zjeździe w Wiślicy. Wprawdzie jej pobyt w Krakowie jest potwierdzony dopiero 5 listopada ${ }^{53}$, ale nie wydaje się prawdopodobne, aby po 31 sierpnia wyruszyła wraz z mężem z Nowego Miasta Korczyna w podróż do Horodła będąc w zaawansowanej ciąży i o tej porze roku (spodziewane jesienne słoty), tym bardziej że nie było żadnego powodu, dla którego taki wysiłek musiałaby podjąć.

Do Horodła zaproszono - jak twierdzi Długosz - tylko tych, którzy godzili się ze zdaniem króla. Dowodnie byli tam: prymas i arcybiskup gnieźnieński Jastrzębiec, biskup chełmski Jan Biskupiec, kasztelan krakowski Krystyn z Ostrowa, wojewodowie: krakowski Jan z Tarnowa i sandomierski Mikołaj z Michałowa, łęczycki Marcin z Rytwian, kanclerz Jan Szafraniec oraz podkanclerzy S. Ciołek ${ }^{54}$. Wielkim nieobecnym był rzeczywiście Oleśnicki. Natomiast podkreślić należy, iż trzej najważniejsi z wymienionych wyżej świeckich możnowładców: kasztelan i wojewoda krakowski oraz wojewoda sandomierski zaliczani są do grona jego bliskich współpracowników i to oni wraz z biskupem krakowskim odbierać mieli później przysięgę oczyszczającą od królowej. Możnowładcy obecni u boku króla w Horodle byli na zjeździe w Wiślicy, skąd wraz z Jagiełłą udali się na spotkanie z Witoldem. Biorąc pod uwage słowa zawarte $\mathrm{w}$ dokumencie Jagiełły, nakazującym $\mathrm{z}$ racji dopuszczenia arcybiskupa Jastrzębca do udziału w zjeździe z Witoldem zawiesić wszelkie roki sądowe przeciwko niemu ${ }^{55}$, oraz relację Długosza, można z całą pewnością stwierdzić, iż nie był to zjazd generalny, w którym prawo uczestnictwa przysługiwało każdemu szlachcicowi, ani też zjazd

52 Annales XI, s. 226.

53 PK, s. 434; G. Rutkowska, op. cit., s. 81.

54 Annales XI, s. 228; ZDM 7, nr 2016, s. 237. W Skokach (23 września) byli poświadczeni u boku króla ponadto: Sędziwój z Ostroroga, wojewoda poznański, oraz kasztelanowie: Dobiesław z Sienna wojnicki, Krystyn z Koziegłów sądecki i Jan z Goźlic radomski. Informacje te zawdzięczam Pani Annie Sochackiej i niniejszym za nie bardzo dziękuję. Szczegółowy opis trasy podróży Witolda do Horodła zawarty jest w: CV, nr 1298, s. $778-780$.

55 „Quia [--] dominum Albertum [--] pro tractandis et disponendis Regni nostri negociis nobiscum assumimus ad convencionem [--] celebrandam Christo duce", KDW 9, nr 1134, s. 96. 
wszystkich dostojników Królestwa. Informacja o zaproszeniu do Horodła pewnych osób wskazuje, że doszło tam do spotkania króla z wielkim księciem w obecności wybranych panów rady. To tłumaczyłoby również nieobecność Oleśnickiego, którego Jagiełło mógł - korzystając ze swoich prerogatyw - na to spotkanie, czyli inaczej zjechanie się obu władców w towarzystwie swoich doradców, nie zaprosićs6. Niewykluczone jednak, że zjazd w Horodle został wstępnie zaplanowany już na początku $1427 \mathrm{r}$. Tam Jagiełło wraz z Witoldem, w obecności panów polskich i litewskich, po sukcesach odniesionych w czasie objazdu swych ziem, zamierzali być może podjąć ponownie kwestię następstwa tronu i nierozwiązanych spraw prawno-ustrojowych. W związku z wydarzeniami, jakie rozegrały się z Wiślicy (oskarżenie królowej), plany te musiały zostać zweryfikowane (łącznie z zaproszeniem do udziału w zjeździe tylko wybranych) ${ }^{57}$.

Stanowisko Witolda w czasie narady w Horodle opisane przez Długosza - jak wyżej podkreślono - zostało już słusznie podane w wątpliwość w literaturze przedmiotu. Poglądy księcia na tę sprawę (przynajmniej oficjalne, bo oceny prywatnej nie jesteśmy w stanie ustalić) zdaje się ukazywać jego list skierowany do panów polskich, w którym wyraża swe zdumienie i oburzenie z powodu tak nikczemnych plotek ${ }^{58}$. W takim kontekście - jeżeli do rozmów na ten temat doszło w Horodle - to nie on oskarżał królową. Wysoce wątpliwe jest zatem także, by domagał się jej surowego i natychmiastowego ukarania. To z kolei rodzi kolejne pytania. Należy zastanowić się, czy rzeczywiście Witold był inicjatorem „natychmiastowego" uwięzienia siedmiu imiennie wymienionych rycerzy, czy to on zabiegał o odesłanie dwórek królowej na Litwę i rzekome ${ }^{59}$ poddanie

${ }^{56} \mathrm{Na}$ temat różnic między obradami króla z radą (w różnych konfiguracjach) a uczestnictwem w zjazdach zob. np. P. Węcowski, op. cit., s. 75 nn. 30 września Oleśnicki wziął udział w posiedzeniu kapituły krakowskiej, zob. KDM 4, nr 1249, s. 239-241.

${ }^{57}$ Szerzej uzasadniam to w pracy: W. Zawitkowska, Walka polityczno-prawna, zwłaszcza s. 154 nn.

${ }^{58}$ LC 1 , nr 83, s. 156-157.

59 Wydaje się mało prawdopodobne, aby zostały one poddane torturom, co uważam za wymysł Długosza nadający dramaturgii całemu wydarzeniu, dlatego też w dalszej części artykułu piszę jedynie o odesłaniu dwórek. Podobną sugestię wysunął już A. Prochaska, zob. Król Władysław, s. 395. Kiedy doszło do usunięcia ich z otoczenia królowej pozostaje kwestią otwartą: mogło to nastąpić wkrótce po rzuceniu oskarżeń pod adresem rycerzy i spotkaniu w Horodle albo przed przysięgą oczyszczającą złożoną przez królową (lub zaraz po tym wydarzeniu). Warto przytoczyć w tym miejscu hipotezę Anny Strzeleckiej, która uwzględniając powiązania rodzinne i klientalne panien Szczukowskich, stwierdziła, iż „zesłanie tych dworek królowej na Litwę było może nie tyle karą, jak chce Długosz, ile oddaniem ich pod opiekę Witoldową nie obcą ich rodzinie od 1399 r. co najmniej" (A. Strzelecka, Kobieta w polityce dynastycznej i w życiu dworskim 
ich torturom. Przypomnieć należy bowiem, że Horodło dzieli od Krakowa ok. $350 \mathrm{~km}$. Co więcej - narady nie trwały zbyt długo - (jedyny dokument polski, podobnie jak litewski, pochodzi z 30 września). Zaraz po tej dacie obaj władcy przez Świerże (2 października) i Brześć Litewski (7 października) wyruszyli na północ, aby w Wilnie tradycyjnie spędzić Boże Narodzenie. Już 26 października Witold był dowodnie w Kownie (ok. $550 \mathrm{~km}$ od Horodła), a Jagiełło, który razem z nim odbywał całą podróż, udał się do Połągi (prawie $800 \mathrm{~km}$ od Horodła) ${ }^{60}$.

Bardzo ważny dla ustalenia chronologii wydarzeń mógłby być list Zofii do Witolda, w którym królowa z wielkim żalem i rozgoryczeniem informuje go o plotkach (prosząc zapewne o pomoc). Niestety nie zachował się on do naszych czasów - wzmianka o nim znajduje się jedynie w przytoczonym wyżej, również niedatowanym liście Witolda do panów koronnych ${ }^{61}$. Nie wiadomo zatem dokładnie ani kiedy został napisany, ani kiedy dotarł do rąk Witolda, ani też, kiedy odpowiedź wielkiego księcia, zawierająca dramatyczny apel do możnowładców polskich, aby nie dawali wiary nikczemnym oszczerstwom rzucanym przez podłych ludzi i umożliwili królowej oczyszczenie się z nikczemnych oskarżeń, została dostarczona do rąk adresatów. Treść listu Witolda, z pewnością znana królowi i przez niego zaakceptowana - niemożliwe wydaje się bowiem kierowanie korespondencji do panów polskich w tak drażliwej sprawie bez jego zgody - zdaje się wskazywać, że decyzja o złożeniu przysięgi oczyszczającej została podjęta dopiero wówczas, gdy nie odniosły skutku wcześniejsze zabiegi. Czy zatem nie było tak, iż to Jagiełło (może nawet jeszcze przed spotkaniem w Horodle) sam podjął pierwsze stanowcze kroki i nakazał np. uwięzienie rycerzy? Ale nawet jeśli taka decyzja zapadła nieco później, w czasie narady z Witoldem, to podkreślić należy,

za panowania Władysława Jagiełty, w: Pamiętnik VI Powszechnego Zjazdu Historyków Polskich w Wilnie 17-20 września 1935 r., t. 1: Referaty, Lwów 1935, s. 125. Por. B. Czwojdrak, Zofia Holszańska, s. 31.

${ }^{60}$ Wprawdzie Długosz podaje, że zjazd rozpoczął się 14 września, lecz nie jest to możliwe - był on wyznaczony na 29 września, zob. KDW 9, nr 1134. Potwierdzają to itineraria zarówno króla, jak i wielkiego księcia, zob. A. Gąsiorowski, op. cit., s. 110; J. Purc, op. cit., s. 105. Obecność króla i dygnitarzy koronnych w Horodle potwierdza dokument z 30 września, zob. ZDM 7, nr 2016. O wyprawie Jagiełły do Połągi, aby zobaczyć morze, którego dotąd - jak donosił Witold w liście do wielkiego mistrza - nie widział, zob. CV nr 1299, s. 780-781. Znowu zatem przekaz Długosza, w którym informuje, że po zakończeniu zjazdu król powrócił na Ruś i tam spędził jesień (Annales XI, s. 228), jest niewiarygodny. Ta wspólna podróż i długi pobyt Jagiełły na Litwie zdają się wskazywać, że w tym czasie nie było między nim a Witoldem żadnych poważniejszych napięć, por. J. Nikodem, Witold, zwłaszcza s. 377.

${ }^{61}$ LC 1, nr 83, s. 156-157. 
że były to działania niekorzystne dla wizerunku królowej i króla, mogące wskazywać na to, iż rzeczywiście doszło do pewnych niegodnych wydarzeń. Co więcej, ponieważ zostały one wprowadzone w życie podczas nieobecności w Koronie władcy, to sytuacja osamotnionej Zofii była bardzo trudna. Brak Jagiełły u jej boku mógł dodatkowo przyczyniać się do rozpowszechnia oszczerstw. Witold, apelując listownie do panów polskich o możliwość oczyszczenia się królowej z zarzutów, pozostawił dowód, jak silna była to plotka i jak bardzo w nią wierzono w stołecznym Krakowie. Siła tej plotki może z kolei wyjaśniać i usprawiedliwiać szybkość oraz stanowczość działań podjętych przez Jagiełłę. W jakim stopniu i w jakim zakresie były te działania inspirowane przez Witolda - w chwili obecnej odpowiedzieć nie sposób ${ }^{62}$.

Przy ustalaniu chronologii wydarzeń należy wskazać na wpis w Podwodach kazimierskich, gdzie pod datą 13 grudnia odnotowany jest przejazd Strasza określonego jako „familiaris” wielkiego księcia63. Nasuwa to przypuszczenie, że to właśnie on, przed tym dniem, przywiózł list Witolda do panów polskich. To z kolei mogłoby dowodzić, że list Zofii do wielkiego księcia został napisany - co sugerował już Antoni Prochaska po zjeździe w Horodle, podczas pobytu męża na Litwie, i potwierdzać tezę, że podjęcie decyzji o złożeniu przysięgi było następstwem braku skuteczności wcześniej nałożonych sankcji ${ }^{64}$.

Zgodnie z informacją podaną przez Długosza o niegodne kontakty z królową miało być oskarżonych aż siedmiu rycerzy ${ }^{65}$. Szczególnie zastanawiająca w tym gronie jest osoba Zaremby z Kalinowy, który pełnił wówczas urząd marszałka wielkiego koronnego (Regni Poloniae) i jest na nim poświadczony aż do 1430 r., kiedy to objął kasztelanię sieradzką, co należy odebrać w kategorii awansu ${ }^{66}$. Niewiarygodne wydaje się bowiem uwięzienie go i równoczesne pozostawienie na urzędzie, a podkreślić należy, że występuje on np. na dokumencie z 11 września wydanym

${ }^{62}$ W. Zawitkowska, Walka polityczno-prawna, s. 157-159.

63 PK, s. 434. Szerzej o „misji” Strasza zob. w dalszej części artykułu.

${ }^{64}$ Nie wydaje się natomiast, aby z tego okresu pochodził list Zofii do Jagiełły, w którym skarży się ona na ból wynikający z rozłąki z małżonkiem, zob. CV, nr 1302, s. 783. Z jego treści, a zwłaszcza zdań, w których królowa martwi się o bezpieczeństwo męża oraz życzy mu sukcesów, należy wnioskować, że powstał on (tak jak proponowała E. Maleczyńska, Rola polityczna, s. 42, i sugeruje G. Rutkowska, op. cit., s. 77, 103) w pierwszym roku pobytu w Polsce, kiedy król wyruszył na wyprawę wojenną do Prus - wbrew A. Prochasce, który jego powstanie ustalał „pod jesień” 1427 r. (CV, nr 1302, s. 783, uwagi wydawcy).

65 Annales XI, s. 227.

${ }^{66}$ Urzędnicy, t. 10, nr 399; Urzędnicy, t. 2, z. 1, nr B 89; A. Szymczakowa, Szlachta sieradzka w XV wieku. Magnifici et generosi, Łódź 1998, s. 95-102. 
w Sandomierzu (w drodze do Horodła), co jednoznacznie wskazuje, że cieszył się jeszcze wówczas pełnią zaufania Jagiełły ${ }^{67}$. Oprócz niego, jako współwinnych, Długosz wymienił: Jana Hinczę z Rogowa, Piotra Kurowskiego, Jana Kraskę z Łubnicy, Jana Taszkę Koniecpolskiego oraz Piotra i Dobiesława ze Szczekocin ${ }^{68}$.

Na podstawie relacji Długosza wiadomo, że bracia Szczekoccy i być może Taszka ${ }^{69}$ udali się na Węgry na dwór Zygmunta Luksemburskiego. Aresztowani zaś mieli zostać wraz z marszałkiem koronnym Wawrzyńcem z Kalinowy: notariusz kancelarii królewskiej Kraska z Łubnicy, Piotr z Kurowa i Hincza z Rogowa. Ten ostatni - w świetle relacji Długosza był najbardziej podejrzany, uciekł nawet z więzienia, ale bardzo szybko go ponownie schwytano i tym razem osadzono w $\mathrm{Chęcinach}^{70}$.

Rycerze oskarżeni przez Długosza należeli, jako dworzanie lub pracownicy kancelarii, do bliskiego otoczenia króla i królowej. W większości byli to rówieśnicy królowej. Stanowili krąg bliskich znajomych, których można nawet określić mianem przyjaciół. Dzięki prowadzonym w ostatnich latach kwerendom w źródłach rękopiśmiennych udało się nawet dokładniej ustalić ich wzajemne powiązania majątkowe, a co za tym idzie, i klientalne ${ }^{71}$. Oskarżenie to mogło zagrozić zatem nie tylko ich reputacji, ale i dalszej karierze.

Królowa, po urodzeniu Kazimierza Andrzeja (30 listopada), a z pewnością przed jego chrztem (21 grudnia), na podstawie decyzji doradców, jak podkreśla Długosz i co można wiązać z sugestią zawartą w liście

${ }^{67}$ ZDM 7, nr 2015; W. Zawitkowska, Walka polityczno-prawna, s. $151 \mathrm{nn}$.

${ }^{68}$ Bibliografia dotycząca ww. osób zgromadzona jest m.in. w: B. Czwojdrak, Miłość i polityka w kręgach dworu królewskiego - królowa Zofia Holszańska i jej rycerze, w: Miłość w czasach dawnych, red. B. Możejko, A. Paner, Gdańsk 2009, s. 121-129.

${ }^{69}$ W literaturze zgodnie dotąd - m.in. ze względu na tłumaczenie Julii Mrukówny (Jana Długosza Roczniki czyli Kroniki sławnego Królestwa Polskiego, ks. 11: 1413-1430, Warszawa 1985, s. 239) - funkcjonowała informacja, że razem z nimi uciekł także Koniecpolski. Jak słusznie zwróciła mi życzliwą uwagę M. Koczerska, wydawcy najnowszego tekstu łacińskiego (Annales XI, s. 227) wyraźnie podają, iż udało się zbiec jedynie braciom Szczekockim („Petro et Dobeslao de Sczekocziny germanis diffugientibus”). Wynika to z faktu, iż za podstawę wydania z 2000 r. przyjęto rękopis, w którym widnieje „Ioannes”, zamiast „Ioanne” (jak w dwóch innych rękopisach). Kwestia ta wymaga jeszcze osobnych szczegółowych analiz.

70 Szerzej zob.: W. Zawitkowska, Walka polityczno-prawna, s. 151-152.

${ }^{71}$ Np. Taszka Koniecpolski występował na przełomie 1428 i 1429 r. jako poręczyciel za długi Kurowskiego, zob. ANK, Księgi grodzkie krakowskie 3, s. 204-205, 207-208; W. Zawitkowska, W stużbie, s. 125. Z kolei zaś B. Czwojdrak wykazała, że w 1430 r. Piotr z Kurowa i Hincza wspólnie poręczali za Przedbora z Szadka, zob. eadem, Rogowscy, s. 59. Możliwe, iż opracowanie szczegółowych biogramów pozostałych oskarżonych wniosłoby nowe informacje do tej kwestii. 
Witolda, za pośrednictwem siedmiu imiennie wymienionych kobiet (sześć matron - mężatek lub wdów - i jedna panna) złożyła przysięgę oczyszczającą. Odebrali ją m.in.: biskup krakowski Oleśnicki, kasztelan krakowski Krystyn z Ostrowa, wojewoda krakowski Jan z Tarnowa oraz wojewoda sandomierski i starosta krakowski Mikołaj z Michałowa ${ }^{72}$. W tym miejscu jeszcze raz zwrócić należy też uwagę na fakt odnotowania w Podwodach kazimierskich pod datą 13 grudnia przejazdu Strasza, określonego jako „familiaris” wielkiego księcia ${ }^{73}$. Może właśnie kilka lub kilkanaście dni wcześniej, po odczytaniu przywiezionego przez Strasza listu Witolda do panów koronnych, zawierającego apel o możliwość oczyszczenia się królowej, doszło do ustalenia treści i formy, na którą zgodziły się zainteresowane strony (zwróćmy uwagę, że wśród odbierających przysięgę byli tylko dostojnicy małopolscy, wystarczyła zatem tylko zgoda ich i królowej), a następnie do złożenia przysięgi? W takim ujęciu posłaniec (czyli Strasz) nie wiózłby z powrotem do króla i wielkiego księcia przebywających na Litwie informacji o urodzeniu się kolejnego syna (ta zapewne już wcześniej została przekazana przez innego umyślnego), ale relację z wydarzeń związanych ze złożeniem przysięgi $i^{74}$.

Po dokonaniu tego aktu można było sądzić, że cała sprawa została doprowadzona do szczęśliwego, zwłaszcza dla pary królewskiej, finału, a pogłoska umrze śmiercią naturalną ${ }^{75}$. I znowu wypada przytoczyć opinię J. Krzyżaniakowej: „oskarżeni rycerze szybko powrócili do łask króla, jeżeli w ogóle je utracili, i nadal pozostawali na dworze lub w kancelarii"76. Rzeczywiście - ich oskarżenie spowodowało, że tylko czasowo zostali usunięci w cień. Warto wskazać w tym miejscu jeszcze raz na przebieg kariery urzędniczej Zaremby. Jeszcze bardziej znamienny jest przykład Taszki Koniecpolskiego. Ponad rok przed wybuchem skandalu (3 I 1426) odnotowany został w źródłach jako „servitor

${ }^{72}$ Annales XI, s. 228-229; W. Zawitkowska, Walka polityczno-prawna, s. 159-161 (tam dalsza literatura).

${ }^{73}$ PK, s. 434.

${ }^{74}$ List Witolda do panów polskich, jak wspomniano powyżej, musiał być najpewniej zaaprobowany przez Jagiełłę. Ponieważ król wyjechał (bez towarzystwa wielkiego księcia) pod koniec października do Połągi, to Witold z odpowiedzią na pismo Zofii wysłane po zjeździe w Horodle czekał na powrót Jagiełły znad morza. W związku z powyższym przyjazd Strasza do Krakowa z listem do panów polskich w tym czasie jest jak najbardziej prawdopodobny.

${ }^{75}$ Wysoce wątpliwe jest, aby w 1427 r. S. Ciołek napisał Cracovia civitas, której końcowe strofy zostały poświęcone królowi, królowej i ich synom: Władysławowi i Kazimierzowi, zob. B. Czwojdrak, Zofia Holszańska, s. 32. Szerzej uzasadniam to w monografii: W. Zawitkowska, Walka polityczno-prawna, s. 267-280.

${ }^{76}$ J. Krzyżaniakowa, J. Ochmański, op. cit., s. 285. 
reginae"77. Po wybuchu skandalu nie pojawił się w otoczeniu Zofii Holszańskiej. Jego kariera rozbłysnęła jednak ze zdwojoną siłą: w 1430 r. był u boku króla w czasie jego ostatniej podróży do Witolda, a w roku następnym wymieniano go wśród najważniejszych osób w państwie (w relacji Długosza i Krzyżaków), a był wówczas tylko notariuszem i sekretarzem. To Taszka, na tym samym zjeździe sandomierskim, na którym odżyła sprawa niewierności Zofii (zob. w dalszej części artykułu), otrzymał od króla nadanie m.in. za wierną, wieloletnią służbę, a dwa lata później (1433) objął najważniejszy urząd koronny - kanclerstwo, które sprawował aż do śmierci, także za rządów synów Jagiełły. Co ciekawe, olbrzymim uznaniem na dworze cieszyła się cały czas jego matka - Konstancja Szafrańcówna. Dowodem tego była zgoda Jagiełły wydana latem $1428 \mathrm{r}$. na wykup przez całą rodzinę tenuty lelowskiej, co uzasadniono przede wszystkim zasługami Koniecpolskiej w opiece nad królewiczami Władysławem i Kazimierzem - czyli tym zrodzonym po wybuchu skandalu ${ }^{78}$. Kariery pozostałych oskarżonych również nie wskazują, aby ponieśli jakieś konsekwencje, a wręcz przeciwnie - w następnych latach zaliczać się będą do osób bardzo blisko związanych z dworem lub kancelarią ${ }^{79}$.

Gdyby Zofia nie była osobą publiczną, cała ta sprawa miałaby charakter li tylko obyczajowy. Niestety, dotyczyła królowej. I choć nie wydaje się, aby ktokolwiek wierzył w możliwość dowiedzenia nieprawego pochodzenia królewiczów, to z pewnością pogłoska uderzała, i to bardzo mocno, w króla i w pozycję polityczną Zofii - pretendującej do roli współregentki podczas małoletniości syna. Nietrudno zauważyć chociażby, jak upokarzająca była dla niej konieczność złożenia przysięgi oczyszczającej, nawet przez zaufane niewiasty. Potwarz godziła także w Witolda, postrzeganego jako protektor Sonki (ponieważ był on zwolennikiem jej małżeństwa z Jagiełłą), a obecnie przewidywanego w planach dworu na współregenta, co znajdowało potwierdzenie w dokumentach homagialnych wystawianych od czasu zjazdu w Brześciu Kujawskim w 1425 r. Podważenie legalnego pochodzenia synów królewskich, a zatem i ich praw do tronu polskiego, mogło zniweczyć plany Witolda co do sprawowania rządów regencyjnych, na czym mu z pewnością bardzo zależało

77 PK, s. 431; W. Zawitkowska, W służbie, s. 122. Ta informacja, jak i charakter służby Koniecpolskiego na dworze królowej zostały pominięte w pracy B. Czwojdrak, Zofia Holszańska, zob. zwłaszcza s. 114.

78 W. Zawitkowska, W służbie, passim. Zob. też opinię J. Nikodema, Spory o koronację wielkiego księcia Litwy Witolda w latach 1429-1430, cz. 2: Próba rekonstrukcji wydarzeń, „Lituano-Slavica Posnaniensia. Studia Historica” 7, 1997, s. 155-171 (zwłaszcza s. 171).

${ }^{79}$ Ich kariery były omawiane wielokrotnie, w związku z czym za zbędne uznałam ponowne przytaczanie obszernej literatury. Wskazówki do niej zawiera przyp. 68. 
i co widoczne jest w korespondencji z lat 1429/1430, kiedy to pojawiła się plotka o zastąpieniu jego osoby jako opiekuna przez wielkiego mistrza (szerzej na ten temat w dalszej części artykułu). Nie należy jednak zapominać, że pogłoski o nieprawym pochodzeniu nadwyrężały także prawa synów Jagiełły do tronu litewskiego, a wobec braku własnych potomków Witold jako swego następcę widział właśnie syna (synów) Władysława Jagiełły ${ }^{80}$. Plotka uderzała również w bliskie otoczenie zarówno króla, jak i królowej - aż podejrzane i niewiarygodne wydaje się oskarżenie o niegodne związki siedmiu rycerzy, dworzan, urzędników lub pracowników kancelarii, bezsprzecznie oddanych stronników pary królewskiej.

Powstanie pogłoski o niewierności Zofii było korzystne nie tylko dla opozycji wewnętrznej, ale i wrogów zewnętrznych. Bezpośredni, uchwytny w źródłach jej związek z polityką widać wyraźnie w 1429 r., kiedy Krzyżacy usiłowali poróżnić Jagiełłę z Witoldem i pojawiały się pogłoski o planach regencji w Polsce zamiast wielkiego księcia (rzekomo rozsiewającego te oszczerstwa) właśnie wielkiego mistrza. Zygmunt Luksemburczyk, dążący cały czas usilnie do skłócenia Jagiełły z książętami mazowieckimi, panami koronnymi i Witoldem, również od początku śledził rozwój wydarzeń (zob. wzmiankowany wyżej list z kwietnia 1427 r. z powinszowaniami z powodu odmiennego stanu królowej). Na ewentualne korzyści Hohenzollernów wskazali ostatnio Jan Tęgowski i Maria Koczerska ${ }^{81}$, która zasugerowała nawet, iż plotka ta powstała na dworze królewny Jadwigi, zaręczonej z synem elektora brandenburskiego. Teza ta jest godna podkreślenia, zwłaszcza że właśnie w 1427 r. (19 listopada). Fryderyk doszedł do lat sprawnych i możliwe stało się zawarcie jego małżeństwa z Jadwigą. Tymczasem treść aktów homagialnych składanych w Haliczu, praktycznie pozbawiała Jagiellonkę wszelkich nadziei na objęcie tronu po ojcu. Wpływ najbliższych dworzan oraz stronników Hohenzollerna („młodego króla”) na powstanie i rozpowszechnianie pomówień jest zatem jak najbardziej prawdopodobny ${ }^{82}$.

${ }^{80} \mathrm{Z}$ pewnością wszystkie te czynniki miały wpływ na oficjalne wzięcie w obronę czci królowej. Inaczej rolę wielkiego księcia w tych wydarzeniach ocenia np. B. Czwojdrak, Zofia Holszańska, s. 30. Szerzej o planach dynastycznych Witolda i Jagiełły zob.: W. Zawitkowska, Walka polityczno-prawna, passim, zwłaszcza s. $75 \mathrm{nn}$.

${ }^{81}$ J. Tęgowski, Stosunek Zbigniewa, s. 76; M. Koczerska, op. cit., s. 84.

82 Szerzej: W. Zawitkowska, Walka polityczno-prawna, passim, zwłaszcza s. 153, 208211. Po przybyciu Fryderyka do Krakowa jego wychowawcami zostali: profesor teologii i dziekan sandomierski Eliasz z Wąwolnicy oraz rycerz Piotr Chełmski. Zwłaszcza ten ostatni, od początku 1430 r. dowodnie bardzo blisko związany z Zofią Holszańską, miał również za zadanie dyskretne śledzenie swego opiekuna. Oprócz nich z pewnością u boku Fryderyka byli jednak zaufani jego ojca (łożni, pokojowcy itd.). 
Z powodów nie obyczajowych, ale politycznych i prawnych powrócono również do tej sprawy na zjeździe sandomierskim w $1431 \mathrm{r}^{83}$ Zwrócić należy uwagę, że miało to miejsce po ożywieniu planów samodzielnej regencji królowej po śmierci Witolda. Tym razem role się odwróciły i to Zofia wystąpiła z oskarżeniem pod adresem Jana Strasza z Kościelnik i Stanisławic h. Odrowąż o to, że ów niesłusznie wobec Witolda i panów litewskich oskarżał ją o niewierność. Główny świadek, który mógł potwierdzić, że to nie on oczerniał królową, już nie żył. Ale warto zwrócić uwagę, że nikt wówczas nie zamierzał również bronić dobrego imienia zmarłego. Nie czyniła tego ani Zofia, ani Władysław Jagiełło, a przecież doskonale znali oni przebieg wydarzeń z 1427 r. i wiedzieli, że królowa sama informowała listownie Witolda o plotkach. Pamiętać także należy, że Strasz był określany w źródłach jako „familiaris” wielkiego księcia i to on najpewniej wiózł list w sprawie przysięgi oczyszczającej do panów polskich pod koniec 1427 r., co automatycznie powodowało, iż stawał się osobą uwikłaną w ten skandal ${ }^{84}$.

Widać więc, że oskarżenie Strasza oparte było na wtórnej wersji plotki - tej z 1429 i 1430 r., kiedy to Krzyżacy o rozsiewanie na Litwie oszczerstw dotyczących nielegalnego pochodzenia synów królewskich posądzili Witolda. Może rzeczywiście zatem w czasie tzw. burzy koronacyjnej wielki książę nieopatrznie publicznie powiedział kilka słów za dużo? Na to pytanie nie można dać jednoznacznej odpowiedzi, chociaż z korespondencji Witolda z wielkim mistrzem wynika jednak, że do końca wielki książę w tej kwestii był lojalny wobec pary monarszej, pełen triumf odniósł zaś misterny plan Krzyżaków, ale zamieszany był w to także tłumacz i pokojowiec króla polskiego Janusz (Hanusz) Stembarski oraz Andrzej Ciołek, blisko spokrewniony z biskupem poznańskim Stanisławem, wiernym stronnikiem króla ${ }^{85}$.

${ }^{83}$ Przebieg tych wydarzeń należy rekonstruować nie tylko na podstawie relacji Długosza (Joannis Dlugossii Annales seu Cronicae incliti Regni Poloniae, lib. 11-12: 1431-1444, Varsoviae 2001 (dalej: Annales XI i XII), s. 15-16), ale przede wszystkim z wykorzystaniem innych źródeł wskazanych już przez A. Prochaskę (Król Władysław, s. 396 nn.), zob. SPPP, t. 2, wyd. A.Z. Helcel, [Kraków] 1870, nr 2354 b (29 III 1431, w wydawnictwie data rozwinięta mylnie na 5 kwietnia), 2341 (11 IV 1431), 2346 (11 XII 1431).

${ }^{84}$ E. Maleczyńska (Rola polityczna, s. 68) zwróciła tylko uwagę na jego bliskie powiązania z książętami mazowieckimi.

${ }^{85}$ Zwrócił na to uwagę A. Prochaska, Król Władysław, s. 396-397. Ostatnio najpełniej problem ten został omówiony w: S. Jóźwiak, A. Szweda, Dyplomatyczna aktywność rycerza Janusza Stembarskiego z Sokołowa $w$ politycznych stosunkach polsko-krzyżacko-litewskich $w$ pierwszej połowie XV wieku, „Komunikaty Mazursko-Warmińskie" 2009, nr 1 (263), zwłaszcza s. 13 nn.; W. Zawitkowska, Walka polityczno-prawna, s. $203 \mathrm{nn}$. 
Koniecznie należy podkreślić, iż w 1431 r. jednym z oskarżycieli był niedawny inkryminowany - Piotr z Kurowa. Już 11 kwietnia na rokach sądowych Strasz złożył przysięgę, iż nigdy nie oczerniał królowej. Zastanawia więc, dlaczego pod koniec roku (11 grudnia) dokonał tego aktu powtórnie. Analizując obie zapiski, można dojść do wniosku, że powodem, dla którego musiał stawić się ponownie przed sądem królewskim, był fakt, iż w pierwszym procesie oskarżającą była tylko królowa Zofia i przysięga dotyczyła wyłącznie jej osoby. Natomiast w drugiej sprawie Sonka występuje wraz z synami i przysięga Strasza obejmuje także królewiczów, co definitywnie zamykało drażliwą kwestię ${ }^{86}$.

Jeżeli to rzeczywiście królowa (a nie król - jak podaje Długosz) dążyła usilnie do zakończenia tej sprawy sądownie, to tym samym kanonik krakowski właśnie jej wystawił świadectwo przebiegłości politycznej i dojrzałości prawnej. Tylko postępowanie sądowe i ostateczny wyrok mogły ostatecznie zakończyć szeroko komentowaną publicznie kwestię rzekomej niewierności królowej i nieprawego pochodzenia królewiczów. Nie tylko Sonka, ale z pewnością także i Jagiełło oraz ich najbliższe otoczenie, nauczeni doświadczeniem, zdawali sobie sprawę, że tak jak zrobili to Krzyżacy, powracając do meritum sprawy po dwóch latach, równie dobrze w przyszłości ktoś inny, po raz kolejny, mógłby tę „skazę” wykorzystać przeciw ich synom.

Wydaje się więc, że nieżyjący Witold, a przy okazji Strasz stali się „kozłami ofiarnymi” planu uknutego na dworze wielkiego mistrza jeszcze przed śmiercią wielkiego księcia, który postanowiła w $1431 \mathrm{r}$. wykorzystać w grze politycznej strona polska. Proces miał na celu ostateczne

${ }^{86}$ Zob.: SPPP 2, nr 2341, 2346. Relacja Długosza (Annales XI i XII, s. 15-16) w tej kwestii zawiera nieścisłości, poczynając od pomyłki w osobie rzekomego kłamcy: był nim nie Jan Strasz z Białaczowa, lecz jego brat. Poza tym zastanowić się należy, czy Strasz został uwięziony. W 1431 r. powinna obowiązywać już zasada „neminem captivabimus nisi iure victum" - zakaz więzienia bez wyroku sądowego zawarty był w przywileju jedlneńskim wydanym 4 marca 1430 r. (CE 1, nr 177). Niewykluczone jednak, że w związku z brakiem potwierdzenia zapisów przywileju jedlneńskiego przez stronę litewską nie wszystkie postanowienia weszły wówczas w życie (por. brak zaprowadzenia prawa polskiego na Rusi). Mocy prawnej postanowienia zawarte w przywileju jedlneńskim nabrały w zasadzie dopiero wraz z wydaniem „bliźniaczego” przywileju krakowskiego i potwierdzeniem umowy grodzieńskiej (styczeń 1433). Owa skomplikowana sytuacja prawna nie wyklucza, że sankcję więzienia wobec Strasza jednak zastosowano, choć jest to w moim przekonaniu bardzo mało prawdopodobne. Szerzej zob.: W. Zawitkowska, Walka polityczno-prawna, s. $256 \mathrm{nn}$.

W tym miejscu za zwrócenie uwagi na pomyłkę A. Prochaski, który niesłusznie do analizy procesu z 1431 r. włączył zapiski odnoszące się do Kraski z Łubnicy h. Bylina (SPPP 2, nr 2344, 2345; A. Prochaska, Król Władysław, s. 400), oraz wszelkie uwagi dotyczące niniejszego artykułu dziękuję Pani Marii Koczerskiej. 
zakończenie sprawy rzekomej niewierności królowej w sposób najlepszy dla niej i dla dynastii (bez zwracania uwagi na wcześniejszą rolę, jaką w tej materii odegrał wielki książę). Zrzucenie całkowitej odpowiedzialności za rozpowszechnianie plotek na nieżyjącego Witolda wprowadzanego w błąd rzekomo przez Strasza zdejmowało przecież dodatkowo cień podejrzenia z tych panów polskich - członków opozycji wewnętrznej, którzy stali za wydarzeniami z roku 1427 i do rozpowszechniania pogłoski się przyczyniali. Proces z 1431 r. był ponadto manifestacją siły dynastii, ukazywał determinację pary królewskiej, która dobitnie pokazała, że wszelkimi metodami (w tym prawnymi) będzie walczyć z każdym, kto odważy się ponownie rzucić taką potwarz. Warto jednak podkreślić, iż udział Strasza w tych wydarzeniach jest co najmniej dwuznaczny. Bardzo prawdopodobne, że odegrał on rolę zgodnie ze scenariuszem przygotowanym przez polityków dworu, którzy w ten sposób zamierzali uzyskać prawne oczyszczenie się z zarzutów królowej, ciągle przewidywanej na regentkę, oraz potwierdzenie legalnego pochodzenia królewiczów ${ }^{87}$.

W świetle powyższych rozważań łatwo dostrzec, że Długosz pod rokiem 1427 złączył w jeden opis dwa różne ciągi zdarzeń. Pisząc o rozpowszechnianiu plotki przez Witolda, przedstawił wersję funkcjonującą pod koniec 1429 i w 1430 r. - wersję, która powstała najpewniej w kręgach krzyżackich i znajduje potwierdzenie w zachowanych listach. I ta późniejsza odsłona plotki o niewierności królowej i nielegalnym potomstwie Jagiełły, wygodna przynajmniej dla części opozycji wewnętrznej, stała się podłożem wydarzeń z 1431 r., na wersję pierwotną zaś spuszczono zasłonę milczenia.

Podsumowując i równocześnie odpowiadając na postawione w tytule artykułu pytanie:

1. Nigdy zapewne nie będzie możliwe uzyskanie odpowiedzi na pytanie, ile w tej plotce było prawdy. Długosz, opisując przebieg wydarzeń, nie wyraził się jednoznacznie w tej kwestii. O niewinności Sonki może przekonywać m.in. postawa Jagiełły, który bardzo łatwo przyjął oczyszczenie się żony poprzez przysięgę i w czasie następnych lat nie okazywał jej niechęci czy braku zaufania. Na niewiarygodność oskarżenia wskazuje z pewnością liczba rycerzy posądzanych o niegodne czyny oraz przebieg ich dalszych karier. Jednak zwrócenie w relacji Długosza szczególnej uwagi na Hinczę z Rogowa jako „głównego” podejrzanego spowodowało, iż w historiografii pojawiły się domniemania o prawdziwości oskarżeń przynajmniej w odniesieniu do tego rycerza. Tezę o bliskich związkach Rogowskiego z królową wprowadziła do obiegu naukowego

87 Szerzej zob. W. Zawitkowska, Walka polityczno-prawna, s. 257-258. 
Janina Kalinowska ${ }^{88}$. Podobne ustalenia przyjęła i rozpowszechniła w szeregu pracach Bożena Czwojdrak ${ }^{89}$, która na poparcie swych twierdzeń wskazywała przede wszystkim następujące argumenty:

a. Starania Hinczy o posiadanie kaplicy w katedrze krakowskiej jak najbliżej miejsca spoczynku królowej Zofii.

b. Notę kommemoracyjną daną przez Hinczę zakonnikom krzepickim z prośbą o modły za duszę królowej.

c. Sprawowanie przez Hinczę urzędu starosty w dobrach oprawnych królowej.

Powyższe argumenty, po przeprowadzeniu szczegółowej analizy, pozostawiają jednak wiele wątpliwości. Kwestia ta wymaga osobnego, szczegółowego omówienia, w tym miejscu zaś ograniczę się do wskazania najważniejszych uwag podważających zarzuty stawiane temu rycerzowi i automatycznie - królowej.

Ad a. Starania o ufundowanie własnej kaplicy rozpoczął Hincza co najmniej trzy lata przed śmiercią królowej ${ }^{90}$. Znajdował się wtedy już w wieku, kiedy podejmuje się rozrachunek z życiem doczesnym (miał ok. 60 lat) i myśli o zapewnieniu godnego miejsca pochówku, zwłaszcza wobec faktu, iż do wieczności odeszli już wówczas niektórzy z jego towarzyszy i przyjaciół. Rogowski nie miał potomstwa, nie zbudował rodzinnej nekropolii w dobrach własnych. Nic dziwnego zatem, że jako „ambitny kasztelan" 91 chciał być pochowany - co ważne, z ojcem i braćmi - w miejscu najbardziej zaszczytnym w ówczesnej Polsce, gdzie swe grobowce miały najmożniejsze i najbardziej wpływowe rodziny. Ale podkreślić należy, że żadne źródło nie potwierdza, iż „od chwili, gdy Rogowski rozpoczął starania o pozwolenie na kaplicę grobową, widać jego determinację ulokowania się jak najbliżej przewidywanego, a później rzeczywistego miejsca spoczynku królowej" ${ }^{92}$. To jedynie Bolesław Przybyszewski zasugerował, iż Hincza chciał wznieść kaplicę w miejscu, gdzie obecnie mieści się kaplica Świętokrzyska, czyli równolegle do

${ }^{88}$ J. Kalinowska, Jan Hincza z Rogowa i jego działalność fundacyjna na dworze pierwszych Jagiellonów, „Analecta Cracoviensia”, t. 19, 1987, s. 318-339, zwłaszcza s. $323,325$.

${ }^{89}$ B. Czwojdrak, Rogowscy, zwłaszcza s. 59-61; eadem, Jan Hincza z Rogowa - rycerz królowej Zofii, w: Faworyci i opozycjoniści. Król a elity polityczne w Rzeczypospolitej XV-XVIII wieku, red. M. Markiewicz, R. Skowron, Kraków 2006, s. 61-66; eadem, Miłość i polityka, s. 121-129; por. eadem, Zofia Holszańska, s. 30-33.

90 J. Kalinowska, op. cit., s. 327 nn.; B. Czwojdrak, Rogowscy, s. 162.

91 Opisując starania Hinczy o uzyskanie prawa do własnej kaplicy, właśnie takiego określenia użyły zarówno B. Czwojdrak (Rogowscy, s. 162), jak i wcześniej J. Kalinowska (op. cit., s. 328).

92 B. Czwojdrak, Rogowscy, s. 162. 
kaplicy Trójcy Świętej, a więc planowanego miejsca pochówku królowej Zofii ${ }^{93}$. Jednakże, co należy szczególnie podkreślić i na co zwróciła uwagę już J. Kalinowska ${ }^{94}$, mógł to czynić z prozaicznego powodu - tylko tam bowiem było wolne miejsce pozwalające na realizację planów „ambitnego" kasztelana, dążącego do wybudowania własnej kaplicy, a nie tylko ufundowania ołtarza. Jak wiadomo - ostatecznie udało się Janowi uzyskać zgodę na budowę kaplicy pw. Przemienienia Pańskiego, która w świetle zachowanych źródeł była pomieszczeniem ciasnym i ciemnym ${ }^{95}$.

Ad b. Krzepice były tenutą królewską, co więcej, już w roku 1457 Hincza zrzekł się sum nań zapisanych, zachowując tylko dożywocie. Powstanie klasztoru kanoników regularnych laterańskich w Krzepicach było w s póln ą fundacją Hinczy i króla Kazimierza - to syn Zofii, w 1466 r., na prośbę Rogowskiego, zgodził się na jego założenie. A „ponieważ powyższe dobra po śmierci Hinczy powinny według prawa wrócić do dóbr królewskich, przeto król, potwierdzając darowiznę, zobowiązuje wszystkich przyszłych starostów tak krzepickich, jako też i brzeźnickich, aby nad niemi mieli tylko opiekę"96 - podkreślał już ks. Stanisław Muznerowski. I to król, wydając dokument fundacyjny: „spodziewa się za zezwolenie na zamianę probostwa [na zakonne - W.Z.] zbawienia swej duszy, oraz dusz: ojca swego Władysława, matki Zofii i brata Władysława"97. Nic więc dziwnego, że to zakonnicy krzepiccy - podkreślmy raz jeszcze: realizując wolę najmłodszego syna Zofii, do których ów żywił „szczególną miłość i uznanie" 98 - w piątki oraz w rocznicę jej śmierci mieli się modlić za niedawno zmarłą królową. Poza tym sądzę, że gdyby relacje między Zofią a Hinczą miały charakter tak bardzo osobisty, to Kazimierz (gdy

93 Wypisy źródłowe do dziejów Wawelu z archiwaliów kapitulnych i kurialnych krakowskich 1440-1500, wyd. B. Przybyszewski, t. 1, Kraków 1960, nr 16, s. 13.

${ }_{94}$ J. Kalinowska, op. cit., s. 327-328.

95 Ibidem, s. 328 nn.; B. Czwojdrak, Rogowscy, s. 163.

${ }^{96}$ Ks. S. Muznerowski, Krzepice w przeszłości, Włocławek 1914, s. 115. Dokumenty Kazimierza Jagiellończyka i arcybiskupa Jana Gruszczyńskiego zachowały się także w późniejszych odpisach, zob. Archiwum Diecezjalne we Włocławku, Akta Archidiecezji Gnieźnieńskiej, Akta Konsystorza Wieluńskiego, 6 (1558-1586;1600-1601), s. 52-60. Za udostępnienie kopii tych dokumentów dziękuję ks. Sławomirowi Zabraniakowi.

${ }^{97}$ Ks. S. Muznerowski, op. cit., s. 114. O tym, że wydając dokument fundacyjny, król prosił o modły w intencji duszy swojej, rodziców i brata, pisała też B. Czwojdrak (Rogowscy, s. 151 nn.). Zob. też ibidem, s. 138-140 (o tenucie krzepickiej). Niestety, nie zwróciła uwagi na te stosunki własnościowe oraz na zapis w dokumencie Kazimierza Jagiellończyka J. Kalinowska (op. cit., s. 325-326), która jak pierwsza, fakt odprawiania w każdy piątek najpierw mszy za duszę Zofii, a potem kolejnej za odpuszczenie grzechów Hinczy uczyniła koronnym argumentem przemawiającym za ich „winą”.

98 Ks. S. Muznerowski, op. cit., s. 114. 
echa rzekomej niewierności były ciągle żywe) nie pozwoliłby na to, aby niegdysiejszy zalotnik (jego domniemany ojciec!) w sposób tak jawny manifestował swoje uczucia. Podkreślić należy także, że wobec licznych fundacji czynionych w tym czasie przez Hinczę, tylko w tym jedynym przypadku (sic!) znane są prośby o modlitwę w intencji Zofii ${ }^{99}$.

Ad c. Sprawowanie przez Rogowskiego urzędu starosty w niektórych dobrach oprawnych Zofii z pewnością wiązało się z zaufaniem, jakim darzono go (i od razu dodajmy - pozostałych uczestników wydarzeń z 1427 r., którzy także osiągnęli ważne, a niektórzy nawet ważniejsze urzędy) na dworze królewskim zarówno za Władysława III, jak i Kazimierza. Należy jednak podkreślić, że sumy zapisane na tychże dobrach oprawnych (Radom, Nieszawa, Chęciny, Inowrocław, Pyzdry) stanowiły zabezpieczenie pożyczek, które Hincza udzielał i królowej, i jej synom, licząc przy tym na wzmocnienie swego prestiżu, jak też korzyści majątkowe. Nie bez znaczenia był fakt, iż część tenut/starostw otrzymał będąc już podskarbim. Były wśród nich miejsca strategiczne, które obejmował w czasie ważnych wydarzeń politycznych (np. Nieszawa, Inowrocław, Pyzdry). Co więcej, Rogowski był starostą nie tylko za życia Zofii, ale i po jej śmierci, kiedy dobra stanowiły oprawę żony Kazimierza Jagiellończyka - Elżbiety Rakuszanki. Czy, a jeżeli tak, to w jakim stopniu miała wpływ na te nominacje osobiście królowa, pozostaje pytaniem, na które źródła odpowiedzi nie dają. Z pewnością zarówno Holszanka, jak i jej mąż oraz ich synowie mieli do Hinczy olbrzymie zaufanie, co sugeruje, że kandydatura Rogowskiego była popierana nie tylko przez królową. Koniecznie należy przy tym podkreślić, że Hincza nie był natomiast starostą w tych dobrach, gdzie Zofia przebywała najczęściej (Sanok, Biecz, Nowy Sącz).

Podsumowując powyższe ustalenia - w mojej ocenie - choć namiętności ludzkie wymykały się, wymykają i wymykać będą z ryz racjonalnych zachowań, to dopóki wina nie zostanie udowodniona, tedy należy domniemywać niewinności i tak też, zwłaszcza w świetle wskazanego wyżej materiału źródłowego i rozwiązań prawnych (dalsze losy obwinionych, przysięga oczyszczająca z 1427 r. i wynik procesu Strasza z 1431 r.), należy przyjąć.

2. Pomówienia królowej Zofii o niewierność małżeńską, zarówno w ujęciu pierwotnym z 1427 r., jak i w zmienionej wersji z lat 1429-1430 czy też kolejnej z roku 1431, nie można rozpatrywać jedynie w kontekście obyczajowym. Oczernianie przeciwników poprzez rzucanie fałszywych oskarżeń było, jest i zapewne będzie jedną z najpopularniejszych metod walki politycznej. Dotyczyć może tak sfery obyczajowej (np. zdrady

${ }^{99}$ Por. B. Czwojdrak, Rogowscy, s. 150 nn. 
małżeńskiej), jak i innych czynów (np. posądzenia o trucicielstwo, a takie oskarżenie również pod adresem Sonki zostało przecież wysunięte).

Rzucenie oskarżeń na Zofię o nieobyczajne zachowanie nie było czymś wyjątkowym na arenie politycznej w tamtym czasie. Należy zwrócić w tym miejscu uwagę na podobne zarzuty, jakie wysunięto pod adresem pierwszej i drugiej żony Jagiełły - Jadwigi Andegaweńskiej i Anny Cylejskiej ${ }^{100}$. Ale od razu należy podkreślić, że dotyczyły one tylko tych królowych, które mogły urodzić następców tronu, a ominęły starszą od poprzedniczek i następczyni Elżbietę Granowską. Nie można zatem przeceniać w tej kwestii ani żywiołowego charakteru i swobodnego sposobu bycia Zofii, ani też różnicy wieku między nią a małżonkiem.

Oskarżenia pod adresem Jadwigi pojawiły się wkrótce po ślubie i jak uczyniła to już np. Krystyna Pieradzka - należy wiązać je z „akcją rakuską", czyli roszczeniami, jakie pod adresem Andegawenki i Korony Polskiej wysuwali Habsburgowie ${ }^{101}$. Związany z tym, ale znany jedynie z relacji Długosza, proces Gniewosza z Dalewic, rozpowszechniającego rzekomo wieści o spotkaniach królowej Jadwigi z Wilhelmem podczas jego kolejnego pobytu w Krakowie ${ }^{102}$, był wielokrotnie omawiany w literaturze przedmiotu.

Historycy już od wielu pokoleń podzielili się na tych, którzy uważają tę relację za wymysł kronikarza ${ }^{103}$, i tych, którzy, choć z pewnymi zastrzeżeniami, uznają wiarygodność przekazu ${ }^{104}$. Zarzuty podnoszone przez negujących proces Gniewosza są następujące:

100 Stąd też najpewniej tytuł książki I. Kienzler, Wierny mąż niewiernych żon Władysław Jagiełto, Warszawa 2011.

${ }^{101}$ K. Pieradzka, rec.: Maciejewska W., Jadwiga królowa polska. Monografia historyczna, „Przegląd Powszechny”, z. dod. 1934, nr III, Kraków, i Strzelecka A., O królowej Jadwidze. Studia i przyczynki, (Arch. Tow. Nauk. we Lwowie, Dz. II, t. XIV), Lwów 1933 (dalej: Recenzja), KH 1935, s. 409-410 (całość s. 401-410).

102 Po raz pierwszy takie oskarżenia Długosz zanotował pod datą 1388, kolejne pod rokiem następnym (opis procesu Gniewosza), zob. Joannis Dlugossii Annales seu Cronicae incliti Regni Poloniae, lib. 10: 1370-1405, Varsaviae 1985 (dalej: Annales X), s. 172, 176-177.

103 Np.: R. Maurer, Proces królowej Jadwigi, „Przewodnik Naukowy i Literacki” 3, 1875, s. 1036-1041; B. Przybyszewski, Jadwiga i Wilhelm, „Analecta Cracoviensia”, t. 7, 1975, s. 141-143; W. Maciejewska, Jadwiga królowa polska. Monografia historyczna, Kraków 1934, „Przegląd Powszechny”, z. dod. 3, passim, zwłaszcza s. 76-77. Ostatnio zaś J. Nikodem, Jadwiga król Polski, Wrocław 2009, s. 144-148. Negację słów Długosza znaleźć można również w literaturze popularnej, zob. np.: A. Zieliński, Oskarżony Jan Długosz, Warszawa 2011, s. 95-101.

${ }^{104}$ Przykładowo: K. Pieradzka, Recenzja, s. 408-410; A. Strzelecka, Z biografii królowej Jadwigi, „Analecta Cracoviensia”, t. 7, 1975, s. 96-98; ostatnio zaś: J. Kurtyka, Tęczyńscy. Studium z dziejów polskiej elity możnowładczej w średniowieczu, Kraków 1997, s. 212. Zob. też: Rozbiór, s. 24. 
a. Brak innych źródeł potwierdzających relację Długosza - zwłaszcza zapisów w księgach sądowych.

b. Określenie Gniewosza w relacji podkomorzym krakowskim (był wówczas kasztelanem wojnickim i starostą sieradzkim).

c. Nieistnienie w ówczesnym prawie polskim kary „odszczekania pod ławą", którą poniósł Gniewosz.

d. Fakt, iż Gniewosz po procesie nie popadł w niełaskę królewską, a wręcz przeciwnie - cały czas cieszył się zaufaniem dworu i zaczął osiągać kolejne urzędy.

Wątpliwości te w zasadniczej części były już wyjaśniane w literaturze przedmiotu ${ }^{105}$. Podsumowując dyskusję w tej kwestii, należy stwierdzić, że:

Ad a. O nieporozumieniach między małżonkami wspominają (choć ogólnikowo) źródła krzyżackie; księgi sądowe mogły się nie zachować, ale też proces o cześć królowej nie musiał odbywać się przed sądem szlacheckim.

Ad b. Określenie Gniewosza w relacji podkomorzym (był nim w latach 1396-1406) nie może podważać wiarygodności Długosza, który wielokrotnie bohaterów relacji opisywał z przydaniem późniejszych urzędów.

Ad c. Kara, którą poniósł Gniewosz, znana jest w ówczesnym prawie polskim ${ }^{106}$.

Ad d. Fakt, iż Gniewosz na skutek procesu nie popadł w niełaskę królewską, może wskazywać na to, że „nie do końca jednak jasny jest jego udział w sprawie oskarżeń" ${ }^{107}$. Oczywiście, dopełnienie małżeństwa czy też powtórne przybycie Wilhelma do Krakowa i rzekome spotykanie z Jadwigą - z pewnością, jak to przekonująco wykazali Jerzy Wyrozumski i J. Nikodem, nie miało miejsca, ale taką wersję rozpowszechniali m.in.

105 Zwrócić w tym miejscu należy na argumenty przytoczone przez Janusza Kurtykę (Tęczyńscy, s. 212, przyp. 183).

106 Podkreśliła to, choć nieściśle, już K. Pieradzka (Recenzja, s. 410). Podobnież J. Kurtyka przyjął, że „przecież w połowie XV w. dziejopis nie mógł wymyśleć nie istniejącej procedury": Tęczyńscy, s. 212, przyp. 183. Zob. też hasło: odszczekiwanie pod ława, w: Z. Gloger, Encyklopedia staropolska ilustrowana, [wersja on-line: http://literat.ug.edu. pl/glogers/ (dostęp: 18 V 2014)], gdzie podano również inne przykłady zastosowania analogicznej kary za oszczerstwo, czyli rzucenie potwarzy. Niewykluczone, iż sformułowanie: „publicznie zaszczekał” należy rozumieć jako „publicznie odszczekał”, czyli publicznie (nie tylko wobec sądu, ale np. wobec obecnych na zjeździe w Wiślicy) odwołał, nie zaś zaszczekał jak pies. Choć możliwe jest w tym względzie również ubarwienie relacji przez kronikarza.

107 J. Sperka, Otoczenie Władysława Opolczyka w latach 1370-1401. Studium o elicie władzy w relacji z monarcha, Katowice 2006, s. 231. 
sami Habsburgowie ${ }^{108}$. Pamiętać jednakże należy, iż niedojście do skutku mariażu Jadwigi z Wilhelmem było również ciosem wymierzonym w Krzyżaków. Polityczno-prawny związek Polski z Litwą, będący konsekwencją małżeństwa z Jagiełłą, powodował, iż jak słusznie zauważył ostatnio J. Nikodem, „dla autorów zakonnych wszystko, co służyć mogło osłabieniu, czy skompromitowaniu Władysława Jagiełły, z punktu widzenia Malborka było niezmiernie pożądane. Nie zawahano się uczynić tego z wykorzystaniem historii Wilhelma i Jadwigi, mimo że Andegawenka nawet po śmierci cieszyła się na ogół dobrą opinią u braci zakonnych"109. Nic dziwnego zatem, że niepochlebne opinie o Jadwidze, połączone z informacjami o dopełnieniu małżeństwa, znajdują się nie tylko w źródłach austriackich, ale też krzyżackich i niemieckich ${ }^{110}$. Natomiast powody, dla których nawet Długosz przyjął taką wersję, przekonująco wyjaśnił ostatnio J. Nikodem ${ }^{111}$.

Przyjęcie argumentów podnoszonych przez J. Wyrozumskiego i J. Nikodema nie wyklucza jednakże faktu posądzenia o rozsiewanie o tym pogłosek Gniewosza, związanego dotąd blisko z Władysławem Opolczykiem (z jego ramienia był opiekunem i przewodnikiem Wilhelma Habsburga w Krakowie). Jak zwrócił ostatnio uwagę Jerzy Sperka, ok. roku 1388 kupił on za 6000 grzywien zamek Ćmielów z przynależnymi wioskami, ta niebagatelna zaś suma mogła pochodzić ze skarbu, który pozostawił uciekający Wilhelm, a Gniewosz - w relacji Długosza - miał go sobie przywłaszczyćc ${ }^{112}$. Zbiegło się to w czasie z zakończeniem procesu kanonicznego, jaki w Kurii Rzymskiej wytoczyli Habsburgowie (późna wiosna lub lato 1388$)^{113}$. W takim wypadku chęć zemsty z ich

108 J. Wyrozumski, Życie i dzieło królowej Jadwigi, w: idem, Królowa Jadwiga. Między epoka piastowska i jagiellońska, Kraków 2006, zwłaszcza s. 87-101; J. Nikodem, Jadwiga, s. $149 \mathrm{nn}$.

${ }^{109}$ J. Nikodem, Jadwiga, s. 130-131. Na ten kontekst zwrócił uwage już wcześniej J. Wyrozumski, op. cit., s. 90.

110 J. Wyrozumski, op. cit., s. 94 nn. W jednej z relacji Jadwiga została nawet nazwana nierządnicą: ibidem, s. 99. Zob. też: J. Nikodem, Jadwiga, s. 128 nn. Oszczerstwa te były jednym z elementów świadomych działań o podłożu politycznym. Jak bowiem podkreślił J. Wyrozumski (op. cit., s. 101): „tak duże zwarcie się rozbieżnych interesów wokół ledwie dochodzącej 12 lat życia Jadwigi musiało za sobą pociągnąć zarówno szereg intryg, jak też odpowiednio nagłośnionych i spektakularnych działań propagandowych".

${ }^{111}$ J. Nikodem, Jadwiga, zwłaszcza s. 142 nn. Jak podkreśliła wcześniej K. Pieradzka, „Dziwne jest, że w prowadzonych przy kancelarii zapiskach mogły się znaleźć obszerne omówienia niedoszłego małżeństwa Jadwigi z Wilhelmem, i to z komentarzem wyrażającym przekonanie, że Wilhelm miał istotnie prawa do królowej i korony" (Rozbiór, s. XXXVIII).

112 J. Sperka, Otoczenie, s. 231.

113 Zabiegi Habsburgów w Kurii Rzymskiej szczegółowo omawia ostatnio J. Nikodem, Jadwiga, s. $153 \mathrm{nn}$. 
strony poprzez rzucenie oskarżenia o rozpowszechnianie plotek na Gniewosza byłaby jak najbardziej uzasadniona ${ }^{114}$. Ale należy jednak zwrócić uwagę na jeszcze jeden aspekt: w maju 1389 r. doszło do dziwnego incydentu krakowskiego, w wyniku którego Opolczyk został oskarżony o próbę zajęcia Wawelu. J. Sperka zwrócił uwagę, że ta historia może wskazywać na prowokację ze strony panów polskich ${ }^{115}$. Janusz Kurtyka przyjął natomiast, iż „kryzys dworski wybuchł w drugiej połowie 1389 r., przecięty zaś został w połowie marca 1390 r."116. Zbieżność chronologiczna (Długosz także pisze o procesie pod rokiem 1389) każe zadać pytanie: czy zatem Gniewosz nie pełnił w otoczeniu Opolczyka (i pośrednio Habsburgów) roli szpiega Jagiełły? ${ }^{117}$ Od tamtej pory ich drogi wyraźnie się rozeszły, Gniewosz zaś zaczął robić karierę u boku króla polskiego. W takim ujęciu nie można wykluczyć, iż za oskarżeniem go o rozpowszechnianie plotek dotyczących Jadwigi stał również Władysław Opolczyk.

Zarzuty kierowane pod adresem Jadwigi musiały mieć dużą siłę. Po złożeniu przez królową na ręce Jana z Tęczyna przysięgi o niewinności pozwano Gniewosza przed sąd. Była to decyzja jak najbardziej słuszna, uzyskanie korzystnego wyroku zamykało bowiem drażliwą kwestię, ucinając równocześnie plotki krążące już wcześniej (oskarżenie kogokolwiek o rzucenie potwarzy było konieczne, aby postawić zarzuty - nie można skierować pozwu przeciwko anonimowej osobie/om). Widać to także w relacji Długosza, który wyraźnie podkreśla, iż od tej pory między małżonkami nie dochodziło do żadnych nieporozumien ${ }^{118}$. Natomiast na fakt, iż Jagiełło w żaden sposób nie wierzył w rzekomą winę Gniewosza, wskazuje to, iż już pod koniec 1390 r. (czyli prawdopodobnie zaledwie kilka miesięcy po procesie) wysłał go do hospodara wołoskiego Mirczy z ważną misją dotyczącą przymierza skierowanego przeciw Zbigniewowi Luksemburskiemu, a zatem miał do niego bardzo duże zaufanie ${ }^{119}$. Niewykluczone w końcu, że Gniewosz celowo zgodził się odegrać taką rolę,

${ }^{114}$ W takim przypadku rację miałby J. Nikodem, który wbrew J. Kurtyce procesu Gniewosza z Dalewic nie wiązał z walką ówczesnych „stronnictw”, zob. Jadwiga, s. 147148; por. J. Kurtyka, Tęczyńscy, s. 212.

115 J. Sperka, Otoczenie, s.160 (opis całego przebiegu zdarzeń: ibidem, s. 156-160).

116 J. Kurtyka, Tęczyńscy, s. 212.

117 Może wówczas powzięto informację (lub nabrano pewności) o podwójnej grze, jaką prowadził z kolei względem króla Władysław Opolczyk? Zob. J. Sperka, Otoczenie, s. 151 nn. (zwłaszcza ocena postępowania księcia zawarta na s. 156).

118 Annales X, s. 177.

119 Zwrócił na to uwagę J. Sperka, Otoczenie, s. 231. O dalszej karierze zob. też: A. Strzelecka, Gniewosz z Dalewic (Dalowic, Ćmielowa, Wronowa), PSB, t. 8/1, Wrocław 1959, s. $143-144$. 
aby możliwe było prawne oczyszczenie królowej z zarzutów (analogicznie jak Strasz w 1431 r. w procesie królowej Zofii).

W podsumowaniu powyższych rozważań, przyjmując prawdziwość zasadniczych tez relacji przedstawionej w Rocznikach, należy jeszcze raz przypomnieć niewątpliwie bardzo ważną uwagę K. Pieradzkiej: „trudno przypuścić, żeby w poł. XV w., gdy pamięć królowej była otoczona głęboką czcią, Długosz decydował się na opis procesu, jeśliby nie istniała w tym względzie powszechna tradycja lub przekaz źródłowy"120.

Jak już wyżej wspomniano, podobne oskarżenia zostały rzucone także na drugą żonę Jagiełły - Annę Cylejską. W relacji Długosza pojawiają się one pod rokiem 1407 i dotyczą trzech rycerzy: Jakuba z Kobylan h. Grzymała, Mikołaja z Chrząstowa h. Strzegomia oraz Andrzeja z Tęczyna h. Topór ${ }^{121}$. Nie poniósł żadnych konsekwencji z tego tytułu najbardziej ustosunkowany z nich Andrzej Tęczyński. Jak przypuszcza J. Kurtyka, był on już zapewne od 1402 r. związany z dworem królowej, a w czasie powstania oskarżenia sprawował urząd podstolego krakowskiego i starosty podolskiego. Po wybuchu skandalu „najpewniej przejściowo usunął się z dworu"122. Drugi z oskarżonych - Mikołaj Chrząstowski z własnej woli udał się na wygnanie, jedynie zaś Jakub Kobylański miał zostać wtrącony do więzienia. Cześć i dobre imię królowej obronił na zjeździe w Niepołomicach arcybiskup Mikołaj Kurowski. Wedle Długosza - sprawcą zamieszania był Klemens z Moskorzowa, były podkanclerzy Królestwa, ochmistrz dworu królowej, który jednakże na rozprawie sądowej miał również odwołać oszczerstwa ${ }^{123}$.

Próbując wyjaśnić motyw pojawienia się owych oskarżeń, E. Maleczyńska zwróciła uwagę na powiązania obu oskarżonych rycerzy z dworem luksemburskim, upatrując w nim właśnie źródło owych intryg dworskich ${ }^{124}$.

${ }^{120}$ K. Pieradzka, Recenzja, s. 410. Tak też: Rozbiór, s. 24. Warto w tym miejscu przypomnieć, iż niepochlebne (choć jeszcze raz podkreślmy - najpewniej rzeczywiście wypowiadane wówczas) opinie o królowej Jadwidze były powodem (wraz z opisem procesu Sonki), dla którego „Annales przez dwa wieki nie mogły ukazać się w druku”: K. Pieradzka, Wstęp, w: Rozbiór, s. XXXVIII.

121 Joannis Dlugossii Annales seu Cronicae incliti Regni Poloniae, lib. 10-11: 1406-1412, Varsaviae 1997 (dalej: Annales X i XI), s. 17-18; Rozbiór, s. 76.

122 J. Kurtyka, Tęczyńscy, s. 273. Co ciekawe, miesiąc później starał się o rękę Anny, jednej z córek Dymitra z Goraja, zaręczyny zaś lub ślub przypadły na styczeń/luty 1408 r. - ibidem, s. 273-274. Wysoce wątpliwe jest, aby opiekunowie Anny oddali ją Andrzejowi w przypadku prawdziwości tychże oskarżeń.

${ }^{123}$ Annales X i XI, s. 18. Zob. też: K. Piotrowicz, Chrzastowski Mikołaj h. Kościesza inaczej Strzegomia, PSB, t. 3, Kraków 1937, s. 473; J. Krzyżaniakowa, Kurowski Mikołaj h. Szreniawa (zm. 1411), PSB, t. 16, Wrocław 1971, s. 261-262.

124 E. Maleczyńska, Społeczeństwo, s. 52. 
Ale nie należy zapominać o bardzo napiętych wówczas stosunkach z Krzyżakami, dla których powstanie nowej dynastii na tronie krakowskim z pewnością nie było pożądane i którzy wrogości do Anny nie ukrywali ${ }^{125}$. Ponadto zwrócić należy jeszcze uwagę na motyw litewski. Echo pewnych oskarżeń pod adresem Anny jest zauważalne w dwóch niedatowanych listach pisanych przez królową do nieznanego księcia. Prosi w nich o wskazanie osób ją oczerniających oraz zapewnia o swej niewinności ${ }^{126}$. Ogólnikowość sformułowań nie pozwala jednoznacznie stwierdzić, czy chodzi tutaj o zarzut niewierności, bez wątpienia jednak oszczercom zależało na podważeniu zaufania adresata listu do królowej. Listy Anny pisane najpewniej do Witolda ${ }^{127}$ potwierdzają, iż doszło do sytuacji, w której została ona oczerniona i niesłusznie oskarżona wobec wielkiego księcia, ów zaś miał dać wiarę tym oszczerstwom. Królowa nie zgadzała się z fałszywym oskarżeniem, prosząc o ujawnienie osoby rzucającej oszczerstwa i o wyjaśnienie tej kwestii listownie lub przez zaufanego posłańca. Zapewniała ponadto, że jest gotowa - jeśli książę uzna za konieczne - poddać się wszelkiej karze i naganie zarówno ze strony męża, jak też adresata. Bez wątpienia zatem intrygi uknute przeciw królowej miały również podłoże w ówczesnych stosunkach polsko-litewskich: Krzyżakom z pewnością zależało na wzbudzeniu nieufności Witolda wobec Jagiełły. Natomiast jaką rolę rzeczywiście w tej historii odegrał Klemens z Moskorzowa i czy poniósł w związku z tym jakieś konsekwencje - nie można stwierdzić - zmarł on bowiem najpewniej pod koniec $1408 \mathrm{r}^{128}$

Oskarżenia pod adresem Anny zawarte są na kartach Roczników jak wyżej wspomniano - pod rokiem 1407. Wzmiankowane wyżej listy pozwoliły K. Pieradzkiej wysunąć stwierdzenie, że sprawa ta „przypada na rok 1408, po urodzeniu Jadwigi 31 III 1408 r."129. Nie można wykluczyć, że podobnie jak plotka o niewierności Zofii, tak również i oszczerstwa dotyczące drugiej żony Jagiełły mogły być rozsiewane przez dłuższy czas, w różnych odsłonach, a wywołać je mogły pierwsze informacje o odmiennym stanie królowej (poczęcie miało miejsce ok. połowy roku

125 Zob. np. A. Strzelecka, Kobieta w polityce, s. 115.

126 Elementa ad fontium editiones, t. 2: „Liber Disparata Antiqua Continens” Alexandro Masoviensi episcopo Tridentino dicatus", wyd. E. Winkler, Romae 1960, nr 40, 41, s. 22; Rozbiór, s. 76.

127 Wydawca źródła, a za nim autorzy Rozbioru (s. 76) przyjęli, iż nadawca listów to „nieznany książę”. Tymczasem stwierdzenie, iż królowa jest gotowa poddać się karze i naganie ze strony męża i jego „najdroższego brata” („domini regis consortis nostri et fratris vestri carissimi"), zdaje się wskazywać właśnie na wielkiego księcia Witolda.

128 I. Sułkowska-Kurasiowa, Moskorzowski Klemens (Klemens z Moskorzowa) h. Pilawa, PSB, t. 22, Wrocław 1977, s. 52-54.

129 Rozbiór, s. 76. Por. B. Czwojdrak, Zofia Holszańska, s. 30. 
1407), co zgadzałoby się z czasem umieszczenia ich w relacji Długosza. Szczęśliwe rozwiązanie, pojawienie się na świecie królewny Jadwigi oraz dobre relacje między małżonkami widoczne chociażby w ich korespondencji ${ }^{130}$ mogły je tylko spotęgować, a nawet wprowadzić nowe elementy oskarżeń, ściśle związane z sytuacją przed wielką wojną: wahaniami wielkiego księcia, czy poprzeć w konflikcie Polskę, oraz kwestią podolską to arcybiskup Kurowski miał przecież namawiać króla, aby wymógł na Witoldzie zburzenie wybudowanych przez niego zamków ${ }^{131}$.

W tym kontekście należy również widzieć kolejną informację Długosza, zawartą pod rokiem 1411. Kronikarz krakowski podał wówczas, iż tenże sam arcybiskup - podczas nieobecności króla - sprawując funkcję regensa, namawiał do niewierności królową, która osobiście miała o tym poinformować męża. W związku z tym Jagiełło zamierzał odprawić sąd nad arcybiskupem w Glinianach, gdzie przybył razem z Witoldem. Kurowski jednakże tam nie dotarł - w drodze na spotkanie spadł z konia i zmarł 7 września $1411 \mathrm{r}^{132}$

Relacja ta budzi szereg wątpliwości zwłaszcza wobec faktu, iż Długosz swej niechęci do Mikołaja nie ukrywał. Nawet jeżeli jakieś pogłoski o zbyt zażyłych kontaktach arcybiskupa z królową mogły się pojawić, to wątpliwe jest, aby ów namawiał ją do złamania przysięgi małżeńskiej. Był on oddanym i zaufanym doradcą, jego postawa w obronie królowej z poprzedniej odsłony skandalu była niezbyt mile widziana przez tych, którym na jej szkalowaniu zależało. Może były to jeszcze echa sprawy poruszanej w listach królowej do wielkiego księcia? Może właśnie tym, którym zawiadomił Annę o oszczerstwach rzucanych pod jej adresem księciu Witoldowi, był Kurowski? Może właśnie wówczas, w 1411 r. w Glinianach, w rozmowie króla, wielkiego księcia i arcybiskupa zamierzano definitywnie zakończyć wszelkie kwestie z tym związane? Na te pytania zapewne nigdy nie otrzymamy odpowiedzi. Jednak po owej dość sensacyjnej opowieści Długosza warto zwrócić uwage, że w okresie pogrunwaldzkim, po poprawie stosunków z Zygmuntem Luksemburskim i umocnieniu kontaktów z Witoldem, brak informacji o dalszych intrygach. Plotki umarły zatem „śmiercią naturalną", ale wpływ na to mógł mieć znaczny wzrost znaczenia i autorytetu króla w tamtym okresie, czego dowodem jest chociażby oficjalne uznanie Jadwigi za następczynię tronu w $1413 \mathrm{r}$.

130 Zob. np. Elementa, nr 34, 35. Inne listy (np. nr 58) oraz pobieżna nawet analiza działalności królowej wskazują wyraźnie na udział Anny w ówczesnych wydarzeniach politycznych (zob. np. A. Strzelecka, Kobieta w polityce, s. 115).

131 Zwróciła już uwagę na to np. E. Maleczyńska, Społeczeństwo, s. 60-61.

132 Annales X i XI, s. 184-185; Rozbiór, s. 136 (tam uściślenie informacji Długosza o dacie śmierci Kurowskiego). 
Analizując wszystkie trzy przypadki rzekomych zdrad małżeńskich polskich królowych, należy zwrócić uwagę, że żaden z nich nie został potwierdzony w świetle prawa; żadna z oskarżonych nie doświadczyła oznak niechęci, nieufności czy odtrącenia ze strony męża; żaden z rycerzy posądzanych o niegodne czyny nie poniósł konsekwencji (najwyżej chwilowe uwięzienie na czas wyjaśniania sprawy), a wręcz przeciwnie, cały czas zaliczani byli oni do wiernych stronników dworu. Trudno zatem założyć, iż Jagiełło byłby tak łaskawy dla wszystkich rycerzy zamieszanych w rzekome skandale $\mathrm{z}$ udziałem jego trzech żon.

Jak w przypadku większości plotek, zwłaszcza tych, które dotyczą osób publicznych i w związku z tym bardzo szybko się rozpowszechniają, niemożliwe jest ustalenie ich pierwotnego źródła. Ponadto, zapewne nierzadko zdarzało się (celowo lub przypadkiem) dokonywanie zniekształceń treści przekazywanych przez kolejną osobę. Każdy, kto pałał niechęcią do osoby spotwarzonej, mógł być autorem pogłoski i uczestniczyć w jej rozpowszechnianiu. Analizując zatem dość pobieżnie - w sposób, na jaki można pozwolić sobie w tym miejscu - zarówno materiał źródłowy, jak też ustalenia poczynione przez kolejne pokolenia historyków, dzięki porównaniu oskarżeń rzucanych pod adresem pierwszych żon Jagiełły oraz Zofii, można założyć, że korzyści z rozpowszechniania wszystkich plotek mieli Zygmunt Luksemburski i Krzyżacy. Oczywiście jak podkreślono już wyżej - nie byli oni jedynymi „beneficjentami”. Oprócz opozycji wewnętrznej, wśród której imiennie trudno wskazać winnych, z oskarżeń pod adresem Jadwigi korzystali z pewnością Habsburgowie, w przypadku Zofii zaś - Hohenzollernowie (przypomnijmy raz jeszcze, jak ważny był dla tych ostatnich rok 1427, kiedy to Fryderyk doszedł do lat sprawnych i mogło zostać zawarte jego małżeństwo z Jadwigą Jagiellonką, oficjalną wciąż następczynią tronu).

3. Sprawa rzekomego cudzołóstwa Zofii Holszańskiej jest zatem doskonałym przykładem plotki politycznej, obliczonej na osiągnięcie konkretnych korzyści przez co najmniej kilka grup interesu. Z tego zapewne względu pojawiły się kolejne jej odsłony, podsycane i rozpowszechniane przez różne osoby (grupy osób), mające w szerzeniu oszczerstw własne, partykularne interesy ${ }^{133}$. W związku $\mathrm{z}$ tym nigdy zapewne nie będzie

133 Niesprawdzone lub kłamliwe pogłoski dotykające osoby publicznej - a taką była Zofia - nie pozostawiają bez uszczerbku wizerunku i autorytetu osoby spotwarzonej i bardzo często odbijają się negatywnie na jej dalszej działalności. Stąd powszechnie wykorzystywane były w walce politycznej. Szerzej na ten temat zob. W. Uruszczak, System władzy w Polsce ostatnich Jagiellonów (1506-1572), CPH 38, 1986, z. 2, s. 41-61, zwłaszcza, s. 52 (tamże definicja plotki politycznej jako środka propagandowego w działalności politycznej). 
możliwe jednoznaczne ustalenie jej pierwotnego źródła, niemniej jednak cele polityczne wygłaszanych wówczas w różnych kręgach opinii nie powinny być już pomijane.

\section{Streszczenie}

Elekcja i koronacja Władysława Jagiełły na króla Polski w 1386 r. dawały możliwość pojawienia się w Europie Środkowo-Wschodniej nowej liczącej się dynastii. Wzbudzało to niepokój sąsiadów (Luksemburgowie, Krzyżacy) dążących do osłabienia monarchii polsko-litewskiej. Próby ustalenia zasad powoływania kolejnych władców oraz zakresu ich prerogatyw aktywizowały również przedstawicieli polskiego możnowładztwa, którzy zabiegali o uzyskanie jak największych wpływów na rządy w państwie. W konfliktach pojawiających się na tym tle wykorzystywano różne metody walki politycznej, w tym plotkę polityczną.

W artykule, po przeprowadzeniu szczegółowej analizy materiału źródłowego (także dotąd nieznanego) i odtworzeniu itinerarium Jagiełły i Zofii Holszańskiej z 1427 r., postawiono tezę, że do wybuchu skandalu związanego z rzekomą niewiernością królowej doszło około połowy sierpnia t.r. na zjeździe generalnym w Wiślicy. Podkreślono przy tym motyw polityczny, związany z bezwarunkowym uznaniem sukcesji tronu po śmierci Jagiełły dla jego pierworodnego syna przez szlachtę ziem ruskich, oraz wskazano na korzyści, jakie mogła w wyniku tych pomówień osiągnąć opozycja wewnętrzna i zewnętrzna, zwłaszcza wobec braku realizacji umowy małżeńskiej Jadwigi Jagiellonki (wciąż oficjalnej następczyni tronu) z Fryderykiem, synem margrabiego brandenburskiego. Postawiono tezę, że z powodów politycznych (walka o regencję) powrócono do tej sprawy na zjeździe sandomierskim w 1431 r., zaś oskarżenie wysunięte pod adresem Jana Strasza było oparte na jeszcze innej wersji plotki, rozpowszechnianej przez Krzyżaków w latach 1429-1430, w którą został uwikłany również wielki książę litewski Witold.

Poczynione w artykule ustalenia wskazują na to, iż Jan Długosz w Rocznikach pod rokiem 1427 złączył w jeden opis dwa różne ciągi wydarzeń: z roku 1427 i z lat 1429-1430, czyli pierwotną i wtórną wersję plotki politycznej, wymyślonej i rozpowszechnianej w celu osiągnięcia korzyści dla kilku grup interesu, której celem miało być osłabienie nowej dynastii - jagiellońskiej.

W artykule wykazano, że podobne oskarżenia, również na tle politycznym, wysuwano już pod adresem dwóch pierwszych żon Jagiełły: Jadwigi Andegaweńskiej i Anny Cylejskiej, a więc tych małżonek, które mogły urodzić następców (dziedziców) tronu. Poczyniono ponadto szereg innych, istotnych ustaleń, m.in. skorygowano opinie dotyczące przyczyn zwołania i przebiegu zjazdu Jagiełły z Witoldem w Horodle w 1427 r. 


\section{Marital Infidelity of Queen Sophia of Halshany in 1427 - Truth, Slander or Political Rumour? Attempted Reconstruction of Events against the Backdrop of Accusations Launched against Jagiełło's Other Wives}

The election and coronation of Władysław Jagiełło as king of Poland in 1386 provided an opportunity for the emergence of a new significant dynasty in Central-Eastern Europe. This fact produced unrest among neighbours (the Luxembourg dynasty and the Teutonic Knights) intent on weakening the Polish-Lithuanian monarchy. Attempts at establishing principles for the enthronement of successive rulers and the range of their prerogatives activated also Polish magnates, who aimed at exerting the greatest possible impact upon state governance. Conflicts appearing against this background made use of assorted methods of a political confrontation, including the political rumour.

After conducting a detailed analysis of the sources (i.a. unknown material) and recreating the 1427 itinerary of Jagiełło and Sophia of Halshany this article proposes a thesis claiming that a scandal associated with the queen's alleged infidelity broke out at a general convention held in Wiślica in the middle of August of that year. At the same time, the author stressed a political motif connected with an unconditional recognition by the gentry of Rus' of the succession to the throne after Jagiełło's death of his first-born son, and indicated the benefits that as a consequence of such slander could have been attained by the domestic and external opposition, especially in view of the fact that a marriage agreement between Jadwiga Jagiellon (still the official heiress to the throne) and Frederick, the son of the margrave of Brandenburg, remained unrealised. The author also formulated a thesis claiming that this question was revived for political reasons (rivalry for the regency) at the Sandomierz convention of 1431, while a charge addressed against Jan Strasz was based on yet another version of the rumour spread by the Teutonic Knights in 1429-1430 and embroiling also Grand Duke Witold of Lithuania.

The ascertainment presented in the article indicates that in his Annales Jan Długosz combined under the year 1427 two sequences of events from 1427 and 1429-1430, i.e. the original and subsequent version of the political rumour devised for the sake of several groups of interest, whose purpose was to enfeeble the new Jagiellonian dynasty.

The article demonstrates that similar accusations, involving a political background, were made also against Jagiełło's first two wives: Jadwiga Anjou and Anna of Cilli/Celje, who could have given birth to successors (heirs to the throne). A number of other essential findings set redresses opinions about the reasons for the convention and the course of a meeting held by Jagiełło and Witold in Horodło in 1427. 


\section{Bibliografia}

Czwojdrak, Bożena. Rogowscy herbu Działosza. Podskarbiowie królewscy. Studium z dziejów możnowładztwa w drugiej połowie XIV i w XV wieku. Katowice: Wydawnictwo Uniwersytetu Śląskiego, 2002.

Czwojdrak, Bożena, Zofia Holszańska. Studium o dworze i roli królowej w późnośredniowiecznej Polsce. Warszawa: DIG, 2012.

Engel, Pál. „Itinerarium Sigismundi regis imperatorisque (1382-1437)” / „Zsigmond király és császár (1382-1437) itineráriumát". W Itineraria regum et reginarum (1382-1438) / Királyok és királynék itineráriumai (1382-1438), 55-159, Budapest: MTA Támogatott Kutatóhelyek Irodája, 2005.

Gąsiorowski, Antoni. Itinerarium króla Władysława Jagiełły 1386-1434. Wyd. 2 popr. i uzup., oprac. Antoni Gąsiorowski i Grażyna Rutkowska. Warszawa: Instytut Historii PAN, 2015.

Jóźwiak, Sławomir, Adam Szweda. „Dyplomatyczna aktywność rycerza Janusza Stembarskiego z Sokołowa w politycznych stosunkach polsko-krzyżacko-litewskich w pierwszej połowie XV wieku". Komunikaty Mazursko-Warmińskie 1 (263) (2009): 3-20.

Kalinowska, Janina. „Jan Hincza z Rogowa i jego działalność fundacyjna na dworze pierwszych Jagiellonów”. Analecta Cracoviensia 19 (1987): 318-339.

Koczerska, Maria. „Królowa Zofia Holszańska - jej osobowość i rola polityczna”. W Kobiety o kobietach. Studia i szkice. Średniowiecze i czasy nowożytne, red. Wioletta Zawitkowska, 76-95. Rzeszów: Wydawnictwo Uniwersytetu Rzeszowskiego, 2010.

Kowalska, Zofia. Stanisław Ciołek (zm. 1437). Podkanclerzy królewski, biskup poznański, poeta dworski. Kraków: Universitas, 1993.

Krzyżaniakowa, Jadwiga, Jerzy Ochmański. Władysław II Jagiełło. Wrocław: Zakład Narodowy im. Ossolińskich - Wydawnictwo, 1990.

Kurtyka, Janusz. Tęczyńscy. Studium z dziejów polskiej elity możnowładczej w średniowieczu. Kraków: Secesja, 1997.

Nikodem, Jarosław. Jadwiga król Polski. Wrocław: Ossolineum, 2009.

Nikodem, Jarosław. Witold. Wielki książę litewski (1354 lub 1355 - 27 października 1430). Kraków: Avalon, 2013.

Purc, Jerzy. „Itinerarium Witolda wielkiego księcia litewskiego (17 lutego 1370 roku 27 października 1430 roku)". Zeszyty Naukowe Uniwersytetu im. Adama Mickiewicza w Poznaniu 74, Historia 11 (1971): 71-115.

Rutkowska, Grażyna. „Itineraria żon króla Władysława Jagiełły”. Roczniki Historyczne 64 (1998): 59-104.

Sperka, Jerzy. Otoczenie Władysława Opolczyka w latach 1370-1401. Studium o elicie władzy w relacji z monarcha. Katowice: Wydawnictwo Uniwersytetu Śląskiego, 2006.

Sperka, Jerzy. Szafrańcowie herbu Stary Koń. Z dziejów kariery i awansu w późnośredniowiecznej Polsce. Katowice: Wydawnictwo Uniwersytetu Śląskiego, 2001.

Uruszczak, Wacław. „System władzy w Polsce ostatnich Jagiellonów (1506-1572)”. Czasopismo Prawno-Historyczne 38, nr 2 (1986): 41-61.

Węcowski, Piotr. Działalność publiczna możnowładztwa małopolskiego w późnym średniowieczu. Itineraria kasztelanów i wojewodów krakowskich w czasach panowania Władysława Jagiełly (1386-1434). Warszawa: DIG, 1998. 
Wyrozumski, Jerzy. „Życie i dzieło królowej Jadwigi”. W Królowa Jadwiga. Między epoka piastowską i jagiellońska, 67-122. Kraków: Universitas, 2006.

Zawitkowska, Wioletta. Walka polityczno-prawna o następstwo tronu po Władysławie Jagielle w latach 1424-1434. Rzeszów: Wydawnictwo Uniwersytetu Rzeszowskiego, 2015.

Biogram: Wioletta Zawitkowska - doktor, starszy wykładowca, zatrudniona w Zakładzie Historii Średniowiecznej i Nordystyki Starszej Instytutu Historii Uniwersytetu Rzeszowskiego; zainteresowania badawcze: nauki pomocnicze historii (zwłaszcza dyplomatyka, paleografia, genealogia, heraldyka, sfragistyka), historia państwa i prawa oraz kultura prawna i polityczna w średniowieczu; e-mail: wipika@wp.pl. 